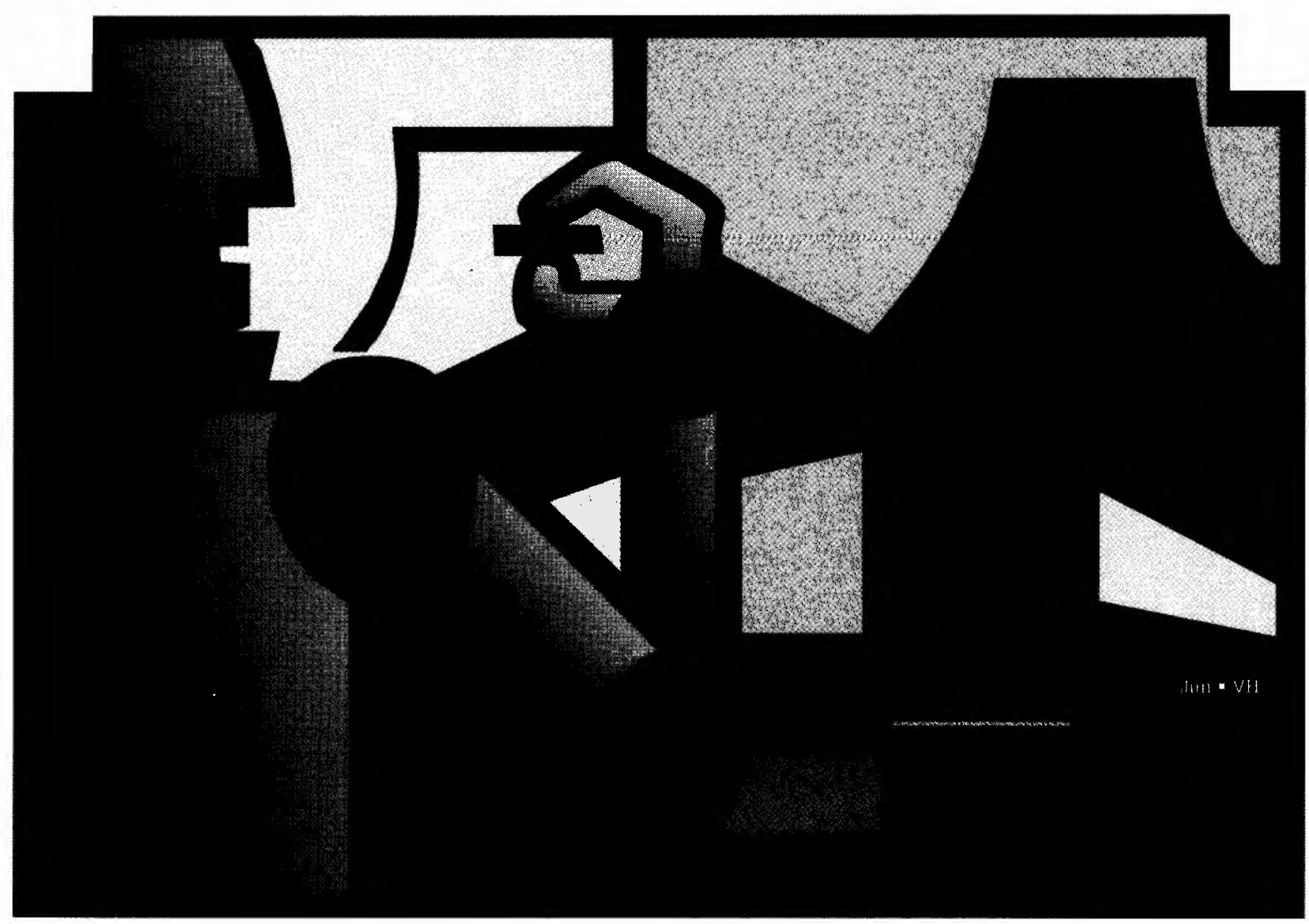

\title{
TECNOLOGIA, INSTRUMENTALIDADE E PODER NAS ORGANIZAÇÕES
}

Stewart R. Clegg

Professor do Departamento de Administração da Universidade de St. Andrews, Escócia.

Tradução de Geni Garcia Golschmidt, revista por Vera Cecilia Machline.

* RESUMO: Derivadas de Maquiavel ou Hobbes, as teorias modernas de poder pressupõem que este emana da tecnologia. Conseqüentemente, elas prevêem que a adoção de novas tecnologias aumenta o controle de poder da administração $e$ a marginalização da mão-de-obra. O presente artigo argumenta que o erro de tais previsões é inerente aos limites dessas teorias, à luz de Foucault; expõe os recentes debates sobre a especialização flexível; finalmente, conclui que mudanças nas técnicas de trabalho engedram resultados distintos. Afinal, tanto o poder quanto as empresas têm contigências complexas $e$ interdependentes, $e$, até certo ponto, são passiveis de mudança.
* PALAVRAS-CHAVE: Poder e tecnologia, especialização flexivel, teorias modernas de poder, poder organizacional e novas tecnologias nas empresas.

* ABSTRACT: Either Hobbessian or Machiavellian in their provenance, modern theories of power assume that all power flows through technology. Thus, they predict that the adoption of new technologies will increase control of power by organizations and marginalization by labor. This article argues that their error is inherent to the limits of these theories, according to Foucault; exposes the recent debates on flexible specialization; at last, it is argued that changes in work techniques have distinct results. After all, the contingencies of both power and organizations are complex, interdependent and, to a point, potentially capable of change.

* KEY WORDS: Power and technology, flexible specialization, modern theories of power, organizational power and new technologies in organizations.

São Paulo, 32(5):68-95 
Numa outra ocasião ${ }^{1}$, predominou uma visão convencional a respeito de poder que se estende desde a explicação de Hobbes de seus fundamentos mecânicos até os debates contemporâneos sobre as "dimensões" do poder ${ }^{2}$, e que perpassa as considerações críticas a respeito do trabalho central de $\mathrm{Dahl}^{3}$. E, em essência, a concepção clássica de Hume do poder como um fenômeno causal é uma constante: fulano logra que sicrano faça algo que eles não fariam em outras circunstâncias; e esses atos são entendidos como uma reação à ação causal do iniciador. Não raro, essa visão causal do poder está vinculada à preocupação de identificar-se as fontes de poder existentes numa determinada arena. Desse modo, fica-se predisposto a enfocar o evento como um jogo de poder de soma zero, no qual uma das partes sempre sairá ganhando às custas da outra. A reação da segunda parte depende da ação da primeira, ação esta que, por sua vez, está subordinada à posse de um recurso raro e valioso.

A concepção de poder como um jogo de soma zero exemplificada por Dahl foi cercada de protocolos empíricos escrupulosos. Obviamente, o resultado ulterior disso foi uma explicação "pluralista" da distribuição do poder em qualquer contexto social. Talvez o poder fosse um jogo de soma zero, mas havia muitas arenas para seu exercício, bem como uma grande variedade de iniciativas e reações da parte das pessoas nelas envolvidas. Conseqüentemente, uma vez que os recursos eram específicos à cada arena - e elas eram muitas - e uma vez que as pessoas se distribuiam em mais de uma arena em vez de se restringirem a apenas uma, Dahl pôde argumentar que, não havendo restrições, seria provável que ninguém nem nenhum grupo deteria a maioria dos recursos na maioria das arenas. Foi por motivos óbvios que essa visão ficou conhecida como "pluralista".

Enquanto os debates sobre poder restringiram-se a questões teóricas amplas ou a arenas acentuadamente pluralistas, como, por exemplo, os espaços urbanos e a diversidade de organizações civis, societais, governamentais e privadas que congregam, dificilmente qualquer discussão incluiria a tecnologia. Isto seria mais provável, contudo, se uma des- sas organizações fosse considerada em particular.

Mas, mesmo neste caso, não havia certeza de nada. Assim, como predominava uma visão convencional sobre poder próxima a uma ortodoxia analítica, convencionou também o lugar da tecnologia na análise das organizações. Por ser imperativa, a tecnologia seria um instrumento neutro para desvendar-se o padrão organizacional; ou seja, talvez respondesse por que as organizações se estruturam diferentemente. Pelo menos foi o que pareceu para a geração de pesquisadores que seguiram os passos de Joan Woodward ${ }^{4}$, mesmo para aqueles que discordavam das conclusões da autora. Lembre-se que, em meados da década de 50 , Woodward estudou cerca de 80 organizações industriais, a maioria delas empresas relativamente pequenas no sudeste da Inglaterra. A autora descobriu que diferenças estruturais entre as organizações conformavam um padrão consistente quando elas foram agrupadas segundo um padrão tecnológico. Três eram os grupos:

1. produção unitária ou em pequenos lotes por organizações que produzem séries reduzidas de artigos sob encomenda ou para projetos independentes;

2. produção em grandes lotes e em massa por empresas onde prevalece um processo de produção contínua e padronizada, como a linha de montagem da indústria automobilística;

3. produção processual por organizações onde predominam séries longas e contínuas, baseadas na repetição dos mesmos procedimentos, como nas petroquímicas e nas refinarias de petróleo.

À medida que se deslocava da primeira para a terceira categoria, havia um aumento gradual da complexidade tecnológica. Outrossim, ocorriam mudanças estruturais patentes. $\mathrm{E}$, à proporção que a complexidade tecnológica aumentava, a organização erigida em torno dela tornava-se progressivamente passível de coordenação por força da padronização dos processos de trabalho. Na produção em massa, isto gerava uma estrutura altamente burocratizada. Já tanto na produção unitária quanto na processual, ha-
1. CLEGG, S.R. "Radical Revisions: power, discipline and organization", Organization studies. 19(1):97-115, 1989.

2. LUKES, S. Power: A Radical view. Londres, MacMillan, 1974.

3. DAHL, R.A. "Power", in International Encyclopédia of the Social Sciences. Nova lorque, Macmillan, pp.405-15,1968.

4. WOODWARD, J. Industrial Organization: behaviour and control. Londres, Oxford University Press, 1965. 
5.HARVEY, E. "Technology and structure of organizations", American Sociological Review, 35 :247-59, 1968; ZWERMAN, W. New perspectives on organizational theory. Westport, Conn., Greenwood, 1970.

6. Como em: BLAU, P. M; FALBE, C.M.; MCKINLEY, W. \& TRACY, P.K. "Technology and organization in manufacturing", Administrative Science Quaterly. $21: 20-40,1976$; HICKSON, D.J.; PUGH,D.S. \& PHEYSEY, D.C. "Operations Technology and Organization Structure: an empirical appraisal", Administrative Science Quarterly. 14: 378-97, 1969; PERROW, C. "A framework for the comparative analysis of complex organizations", American Sociological Review. 32:194-208, 1967; THOMPSON, J.D. Organizations in action. Nova lorque, McGraw Hill, 1967; VAN DE VEN, A.H. \& DELBECQ. "A task-contingent model of work-unit structure", Administrative Science Quarterly. 19.183-97, 1974.

7. MARSH, R.M. \& MANNARI, H. "Technology and size as determinants of the organizational structure of Japanese factories", Administrative Science Quarterly. 26(1):33-57, 1981; TAYEB, M. Organizations and national culture. Londres, Sage, 1988

\section{WOODWARD, W. Op. cit}

9. JACQUES, E. The Changing culture of a factory. Londres, Tavistock, 1951.

10. FOX, A. Beyond Contract. work, power and trust relations. Londres, Faber and Faber, 1974.

11. ALDRICH, H.E. "Technology and organizational structure: a re-examination of the findings of the Aston Group", Administrative Science Quaterly. 17:2642, 1972

12. TAYLOR, F.W. Principles of scientific management. Nova lorque, Harper, 1911.

via menos burocratização, mas por motivos diferentes. A produção unitária era menos burocratizada porque era uma estrutura relativamente simples; baseava-se na vigilância pessoal e na especialização dos empregados. Por empregarem menos especialistas, as empresas desta categoria eram menos especializadas, e as relações entre a administração e os trabalhadores tendiam a ser menos formais. Por sua vez, a produção processual empregava mais especialistas, mas eles eram incorporados principalmente junto à administração. Em conseqüência do alto nível de es-

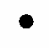

$\bullet \bullet \bullet \bullet \bullet \bullet \bullet \bullet \bullet \bullet \bullet \bullet \bullet \bullet \bullet \bullet \bullet \bullet \bullet$

\section{Em conseqüência do alto nivel} de especialização da força de trabalho e da natureza altamente padronizada do trabalho, a estrutura das organizações tendia a ser mais flexível do que a burocracia das empresas de produção em massa. pecialização da força de trabalho e da natureza altamente padronizada do trabalho, a estrutura das organizações tendia a ser mais flexível do que a burocracia das empresas de produção em massa; também, costumava ter uma estratificação mais difusa. A burocracia da produção em massa operava com os mais elevados níveis de padronização, os mais baixos níveis de especialização e os mais altos graus de formalização e estratificação.

Hoje, essas conclusões parecem evidentes. Antes do trabalho de Woodward, todavia, ninguém havia observado tais relações. $O$ fato de agora parecerem óbvias não diminui os méritos da estudiosa. As organizações de produção em lotes tendem a ser menores, em parte porque empregam menos especialistas. A tomada de decisão geralmente é feita durante a produção de cada item. Mormente tem implicações com um produto específico, e não com o sistema em geral. Ademais, não requer uma burocracia complexa. $\mathrm{O}$ oposto ocorre na produção em massa. A natureza do produto exige menos decisões, mas cada decisão afetará o sistema e terá um impacto mais duradouro posto as séries são menos numerosas e bem mais extensas. Os baixos níveis de especialização da força de trabalho significa que a produção em massa requer mecanismos de coordenação mais padronizados e mais formalizados. Portanto, Woodward forneceu não só uma descrição, mas também uma explicação para as diferenças estruturais das organizações; aliás, uma explicação que grangeou apoio ${ }^{5}$, influência ${ }^{6}$ e crítica ${ }^{7}$.

Subjaz às idéias de Woodward ${ }^{8}$ uma teorização de poder. É ela que associa o intervalo de tempo entre o arbítrio administrativo9, qual seja, a capacidade dos erros de julgamentos específicos da administração de reverberarem e amplificarem ao longo do sistema organizacional por mais ou menos tempo, à concepção de confiança administrativa ${ }^{10}$, que se fundamenta na apreciação das especializações da força de trabalho. Isto, contudo, não foi efetivamente desenvolvido por Woodward, nem por seus críticos de orientação empírica pertencentes à Escola de Aston, que se preocuparam mais em limitar conceitualmente o poder determinante da tecnologia e favorecer o impacto do tamanho na estrutura da organização. ${ }^{11}$

A teoria organizacional de uma política tecnológica implícita em Woodward contrasta acentuadamente com a visão ortodoxa de administradores e engenheiros, na qual a política se notabiliza por sua ausência. $O$ poder é omitido em face a uma garantia implícita de integridade de princípios fundamentada na autonomia atribuída à ciência, cujas aplicações seriam fruto de avanços do conhecimento puro. $\mathrm{O}$ argumento "da engenharia" alegaria que a tecnologia equivale ao progresso; que é natural, neutra e inevitável; e precisa ser administrada apenas quando de sua introdução para minimizar problemas irracionais ligados à adaptação social. O desenvolvimento tecnológico é inerentemente bom e deveria ser bem-vindo; e qualquer oposição seria ilegítima. $\mathrm{O}$ engenheiro sabe qual é o "melhor" método de produção, o mais eficiente e eficaz modo de produção; ele dispõe de dados "objetivos" para sustentar suas decisões, por exemplo, exercícios de justificação de custos. A "administração científica", desde F. W. Taylor ${ }^{12}$ até 
a atual ergonomia, é o melhor exemplo desta tendência.

A administração científica, combinada com o avanço tecnológico, pode levar a um maior controle do processo de trabalho através da especialização do trabalho e da retirada do operador da tomada de decisão. Isto freqüentemente implica no maior controle da administração e na perda de autonomia e de tomada de decisão do operador. De modo geral, o indivíduo é considerado em termos puramente instrumentais, ou seja, como um operador que pode ser manipulado e ajustado através de treinamento e incentivos; suas ações devem ser orientadas tendo-se em vista basicamente os objetivos da organização. A mão-de-obra é um instrumento para a produção que, assim como a tecnologia, cumpre ser usada o mais eficiente e eficazmente possível. A eficiência poder ser quantificada de modo científico e sem valoração, o que não ocorre com considerações mais secundárias, como, por exemplo, as disposições sócio-psicológicas dos indivíduos. $O$ que o engenheiro considera um empregado desiludido, descontente e descompromissado com seu trabalho pode ser também facilmente interpretado como ociosidade e relutância. A possibilidade de que o descontentamento pode ter sido gerado pelo modo como a organização do trabalho é estabelecida e pela maneira como as mudanças técnicas são introduzidas, assim como pela ausência de participação do empregado na tomada de decisões e pelo descaso da administração para com as disposições do empregado, poderia evidenciar um círculo vicioso em potencial: o aumento do poder visando a restringir o controle estaria gerando uma resistência progressivamente maior. Tais considerações sobre a relação entre poder e tecnologia estão bem estabelecidas. Talcott Parsons ${ }^{13}$ observou que o avanço tecnológico quase sempre leva a uma divisão do trabalho gradativamente mais elaborada e a uma organização cada vez mais sofisticada. Entendida como uma força autônoma, a tecnologia determina as necessidades do sistema. Naturalmente, a força autônoma deve resultar de escolhas da administração quanto à divisão do trabalho, conforme reconheceu Dreyfuss $^{14}$. Warner \& Low $^{15}$ sugeriram que problemas de controle são simplificados na medida em que as máquinas parecem ser mais fáceis de controlar que pessoas. Além disso, como reconheceu Durkheim $^{16}$, a mecanização não apenas rompe a solidariedade social dos trabalhadores menos qualificados, como também ajuda a destruir o sentimento de segurança que o antigo artesão derivava de suas especializações técnicas especiais.

O insight de Durkheim tornou-se o fundamento tácito mas difarçado de uma explicação influente do "processo trabalhista". Foi uma explicação que, simultaneamente, aceitava a visão convencional de poder como um jogo de "soma zero", mas que era expresso por intermédio da tecnologia. Além disso, ela propunha uma análise radical. Mas, o que estava em discussão era a análise neo-marxista. Tecnologia e poder foram reunidos num modelo gerado pela onda do "processo trabalhista" iniciada em Labour and Monopoly Capital, de Braverman ${ }^{17}$, também socorrida na contemporaneidade por escritores como Marglin e Stone ${ }^{18}$. Em trabalhos deste gênero, poder e tecnologia foram combinados com a intermediação do conceito de controle. O poder seria como preconizava o conceito predominante, enquanto que a tecnologia seria o meio pelo qual ele era mobilizado. Nos termos da reprodução do controle capitalista exercido sobre os meios de produção na supervisão diária do processo de trabalho, o controle tornou-se a meta para orientar poder e tecnologia.

Exemplos históricos clássicos foram oferecidos por Marglin e Gorz ${ }^{19}$ cita o caso dos mercadores de algodão e lã que desenvolveram para si próprios uma função ao utilizarem a tecnologia para controlar as atividades de seus trabalhadores, em vez de simplesmente aumentar a eficiência. Sugeriu-se que uma tecnologia muito diferente poderia ter sido desenvolvida se o principal objetivo não tivesse sido o controle máximo. ${ }^{20}$ Dentre os escritores que deram um enfoque ao mesmo tempo contemporâneo e histórico, Braverman ${ }^{21}$ também argumentou que as tecnologias são geralmente escolhidas por outras razões além do aumento de eficiência. A máquina oferece à administração a oportunidade de acompanhar e controlar cada etapa, de acordo
13. PARSONS, T. The Social system. Nova lorque, Free Press, 1951.

14. DREYFUSS, C. Occupation and ideology of the salaried $\mathrm{em}$ ployee, tradução de E. Abramovitch. Nova lorque, Basic Books, 1938.

15. WARNER, W.L. \& LOW, L.0. The social system of the modern factory. Cambridge, Yale University Press, 1947.

16. DURKHEIM, D. The division of labour in society. Nova lorque, Free Press, 1964.

17. BRAVEMAN, $H$. Labor and Monopoly Capital: the degradation of work in the twentieth century. Nova Iorque, Monthly Review Press, 1974.

18. MARGLIN, S.A. "What do bosses do? - the origins and functions of hierarchy in capitalist production", Review of Radical Political Economics. 6: 60112, 1974; STONE, K. "The origines of job structures in the steel industry", Reviews of Radical Political Economics. 6:11374, 1974.

19. Idem, ibidem; GORZ, A. "Technical intelligence and capitalist division of labour, Telos. 12:27-41,1972.

20. Idem, ibidem.

21. BRAVEMAN, H. Op. cit 
22. WATANABE, T. "New office technology and the labour process in contemporary Japanese banking". New technology, work and employment. 5(1):56-67, 1990.

23. LANE, C. "Capitalism or culture? A comparative analysis of the position of the labour process and labour market of lower white-collar workers in the financial services sector of Britain and the Federal Republic of West Germany", Work employment and society. 1:57-84, 1987; PRICE, R. "Information consultation and the control of new technology", in HYMAN, $R$. \& STREECK, W.(Org.) NeW technology and industrial relations. Blackwell, 1988.

24. KNIGHTS, D. \& A. STURDY, $M$. 'Women's work in insurance - information technology and the reproduction of gendered segregation", in DAVIDSON, M.J. \& COOPER, C.L.(Org.) Women and information technology. John Wiley and Sons, 1987.

25. BEYNON, H. Working for Ford. Harmondsworth, Penguin, 1974.

26. NICHOLS, T. \& BEYNON, H. Living with capitalism. Londres, Routledge and Kegan Paul, 1977

\section{MARGLIN, S. A. Op. cit.}

28. BRAVEMAN, H. Op. cit.

29. BURAWOY, M. "Towards a Marxist Theory of the Labour Process: Braverman and $\mathrm{Be}-$ yond", Politics and society. 8.247-312, 1978 . com as decisões centralizadas em suas mãos. Portanto, o controle administrativo pode aumentar com mudanças tecnológicas. Watanabe ${ }^{22}$ descreveu como trabalhadores perderam suas especializações e tiveram diminuída sua posição no setor bancário japonês, embora Lane e Price ${ }^{23}$ tivessem sido mais otimistas em seus estudos sobre o setor bancário em outros lugares. Knights \& Sturdy ${ }^{24}$ argumentaram que houve um aumento considerável do trabalho rotineiro em empresas seguradoras, conduzindo à polarização de especializações. Beynon ${ }^{25}$ e Nichols \& Beynon $^{26}$ descreveram os efeitos da imposição de tecnologia em rotinas de trabalho. Ora, se a tecnologia leva a julgamentos, deliberações e decisões redundantes, as oportunidades dos indivíduos de resistirem estariam eliminadas ou seriam reduzidas. Por outro lado, existiria uma nova função central para o administrador, conforme chegaram a sugerir os primeiros estudos de casos, como, por exemplo, os realizados por Marglin. ${ }^{27}$

$\mathrm{Na}$ literatura sobre o "processo trabalhista", controle invariavelmente significa o controle capitalista deste processo, postergando questões a serem analisadas sobre a organização, que foram negligenciadas por Marx há um século atrás. Aqueles que inauguravam os processo de poder foram metaforicamente concebidos como o "capital" e seus emissários; os que reagiam ao poder foram por sua vez metaforicamente concebidos como "trabalhadores". Em concepções consideradas mais sofisticadas em relação a esta abordagem, posteriormente permitiu-se iniciar um tipo específico de ação: a resistência. Entretanto, como o poder era sempre exercido numa estrutura onde o controle capitalista não havia sido extinto, esta resistência nunca chegaria a destronar o poder no controle dos recursos, nem poderia jamais alterar a direção seguida por aquele poder.

No gênero de estudos que se seguiu, o controle era sempre problemático. As dificuldades para sua efetivação surgiam porque ele era exercido sobre seres humanos que detinham o controle sobre sua corporalidade e subjetividade, apesar de alugarem seu tempo para um empregador. Este último, geralmente apresentado como um capitalista (uma designação que apresenta problemas quando da análise de formas organizacionais como empresas estatais, cooperativas ou o serviço público), tinha que ser capaz de converter o tempo alugado dos trabalhadores num poder de trabalho efetivo. $O$ uso efetivo do tempo alugado significava obter de volta um valor excedente maior que o consumido no aluguel - $o$ valor de troca ou custo da remuneração do trabalho. Realizar isto exigia uma estreita supervisão do processo trabalhista no qual ocorreria a transformação alquímica de valores. Braverman ${ }^{28}$ sugeriu que, ao longo da história, o principal expediente para lograr-se tal alquimia foi "a degradação trabalhista no século vinte" através de processos de "des-especialização". Esta, ou a redução da especialização contida no trabalho, foi o modo como o trabalho foi barateado, disciplinado e marginalizado no que teria de possibidades organizacionais e cognitivas. Isto foi conseguido devido à inovação tecnológica. Em vez da tecnologia ser uma composição derivada a partir de uma nota neutra, seus ritmos interiores emanariam de uma nota de dominação e controle. Na melhor das hipóteses, a orquestração permitiria intervalos ocasionais ou interrupções no projeto. Em alguns escritores como Burawoy ${ }^{29}$, mesmo aparentes vislumbres de outras possibilidades deveriam ser considerados formas ainda mais complexas do contraponto harmônico ao tema principal da dominação. A resistência sem sintonia funcionava em harmonia com a hegemonia, mesmo quando à primeira vista parecesse estar desafinando.

Para o movimento conscientemente radical pertencente à análise social, a avaliação do poder abordada a partir do "processo trabalhista" era surpreendentemente ortodoxa. $O$ poder era um jogo de soma zero: os capitalistas teriam mais desde que os trabalhadores tivessem menos. Tratava-se de um fenômeno causal baseado no controle dos recursos. E revelava-se em atos concretos de ação $e$ reação (esta última tida como resistência). A tecnologia também tinha uma função específica. Era concebida de modo bastante concreto, como maquinário e processos relacionados constituindo os meios pelos quais o poder tinha início e, não raro, o controle efetivava-se (nova- 
mente). As mudanças tecnológicas indicavam mudanças no controle do trabalho. Embora não fossem os únicos índices ou meios de controle, posto que poderiam estar "sedimentadas" em níveis e camadas bastante complexos ${ }^{30}$, elas foram alvo de especial interesse pelos autores interessados no processo trabalhista. ${ }^{31} \mathrm{Al}-$ guns pesquisadores como, por exemplo, Storey $^{32}$, efetivamente descortinaram em certas formas "novas" de tecnologia um dispositivo em potencial, capaz de integrar toda a gama de controles aos quais uma organização normalmente recorre. A partir desta perspectiva, seria possível supor que todo poder emanaria da tecnologia, e que o futuro das organizações que adotariam estas tecnologias seria um crescente controle do poder e, portanto, uma crescente marginalização da resistência num universo cada vez mais "unidimensional", bastante semelhante ao previsto por Marcuse. ${ }^{33}$ Iremos argumentar que essas previsões são espúrias, e que seu erro é inerente aos limites das teorias de poder que as fundamentam.

\section{TEORIAS DE PODER}

A maioria das modernas teorias de poder provieram de Hobbes. E quando não é este o caso, geralmente revelam uma linha maquiavélica. Resumidamente, esta foi a meta-argumento de um livro recente sobre "poder". ${ }^{34}$ Nesta seção, procuraremos elaborar esse argumento e demonstrar que existem outras possibilidades para teorizar poder e tecnologia além daquelas que terminam no cenário de um controle quase que total, como o descrito por Storey. ${ }^{35}$

A diferença entre Hobbes e Maquiavel pode ser expressa em termos bastante simples. Pode-se dizer que, enquanto Hobbes e seus sucessores legislaram indefinidamente sobre o que o poder seria, Maquiavel e seus sucessores interpretaram o que ele faria. A distinção entre "le- gisladores" e "intérpretes" é emprestada de Zygmunt Bauman. ${ }^{36}$ Ela procura apreender a diferença entre um conhecimento cuja origem está integralmente vinculada ao poder do estado, e um outro que estaria divorciado dele. Nesse sentido, Hobbes, que foi o protótipo dos teóricos modernos do poder, seria um legislador clássico. Ele forneceu uma explicação racional da ordem que o poder do estado poderia produzir. Além disso, ele servia aquele poder. O Leviatã de Hobbes foi "um discurso relativamente autônomo, auto-administrativo" ${ }^{37}$ que gerou um modelo explícito de ordem. Já as preocupações de Maquiavel diziam respeito à necessidade de um certo distanciamento da função do legislador. Ele não servia a um poder de um estado unificado e forte; $\mathrm{e}$ foi rejeitado pelo poder do estado em que residia. Ademais, não tentou produzir um modelo de ordem para legisladores. Maquiavel, ao contrário de Hobbes, escreveu apenas para interpretar as estratégias do poder, não para fixar o poder ou servi-lo. De àcordo com os critérios de Bauman (1987), ele foi "pós-moderno" antes mesmo do advento da modernidade! Um intelectual escrevendo sobre estado e poder, não obstante isolado de ambos por força da política de seu espaço e de seu tempo. Talvez por este motivo Maquiavel seja um modelo tão sedutor para alguns estudiosos contemporâneos do poder.

Estes últimos não são os únicos que consideram Maquiavel útil. Por exemplo, a ênfase de Florentine coincide em alguns pontos com as preocupações estratégicas, locais e práticas implícitas na invocação do Príncipe Moderno de Gramsci. ${ }^{38}$ As preocupações estratégicas de Maquiavel, que não tinham nenhum matiz totalitário, também atraíram escritores em fins do século XX, como Laclau \& Mouffe.$^{39} \mathrm{Na}$ dissecação de Foucault ${ }^{40}$ das práticas discursivas, também podese observar uma preocupação estratégica mas não totalitária do poder. Isto não
30. CLEGG, S.R. "Organization and control", Administrative science quarterly. 26(4):545-62, 1981.

31. Ver os colaboradores do volume publicado por KNIGHTS, D. \& WILMOTT, H. Labour process theory. Basingstoke, MacMillan Press, 1990.

32. STOREY, J., "The means of management control", Sociology. 19 (2): 193-212, 1985.

33. MARCUSE, H. One dimensional man. Londres, Routledge and Kegan Paul, 1964.

34. CLEGG, S.R. Frameworks of power. Londres, Sage, 1989.

35. STOREY, J. Op. cit.

36. BAUMAN, Z. Legislators and interpreters. Cambridge, Polity Press, 1987.

37. BAUMAN, Z. Op. cit., p.2.

38. GRAMSCI, A. Selection from the prison notebooks. HOARE, Q. \& SMITH, G.N.(Org. e trad.), Londres, Lawrence and Wishart, 1971.

39. LACLAU, E. \& MOUFFE, C. Hegemony and socialist strategy. Londres, Verso, 1985.

40. FOUCAULT, M.The Archeology of knowledge. Londres, Tavistock, 1972. (Edição brasileira traduzida por NEVES, Luis Felipe Bada. A Arquelologia do saber. Petrópolis, Vozes) 
significa que Foucault seja um descendente intelectual direto de Maquiavel. Isto seria uma ironia, considerando-se as restrições de Foucault (1972) quanto ao mito das origens em A Arqueologia do Saber. Muito pelo contrário, cumpre reconhecer que os dois autores lidaram com uma problemática similar. Para Maquiavel, tratava-se de interpretar que apenas a estratégia e a organização podem garantir uma totalidade de poder organizada, num cenário caracterizado por um fluxo, ou um vórtice, político. A preocupação de Foucault em trabalhos posteriores foi a maneira como estas totalidades organizadas ocorriam na forma institucional e na prática discursiva; ou seja, as que asseguraram "o nascimento da clínica", bem como as que poderiam ter erigido o poder da "observação médica" e ou a "disciplina médica". Quais estratégias e organizações garantiram esses resultados consideráveis? E sua continuidade é sobretudo um problema.

Hobbes, ao contrário de Maquiavel, procurou legitimar um mito de ordem fundamentado na soberania. Não surpreende que, escrevendo mais de um século depois de Maquiavel, sua obra refletisse os instrumentos mais poderosos na construção da ordem então à disposição dos primeiros estudiosos modernos: o discurso da mecânica, a formulação inaugural do que viria a se tornar o cerne da ciência "moderna". Dado o enorme sucesso do projeto científico, também não surpreende que na conceituação do poder, assim como de muitas outras coisas, os primeiros cientistas políticos e sociais procuraram equiparar a terminologia e as metáforas adotadas às noções concebidas por seus contemporâneos no âmbito da Mecânica. Estrategista frustrado e pretenso conselheiro calculista do príncipe de um estado secundário e irrelevante, Maquiavel foi naturalmente consignado, à exceção de certas tradições européias, a um papel basicamente histórico na teoria política, e não a um que pudesse ser posteriormente considerado uma metáfora do que viria a se constituir no projeto de poder da modernidade.

Em vista do contexto e dos destinatários desses primeiros debates modernos, quando são examinados hoje, não é difícil captar o sentido do projeto ma- quiavélico. Ele representa uma visão de poder abrangente: talvez até mesmo mais relevante nestes assim chamados "tempos pós-modernos" que o vitorioso projeto modernista, cujos fundamentos foram estabelecidos por Hobbes. O projeto deste último caracterizava-se por um impulso narrativo orquestrado por aquele produtor de lei mítico, heróico e moderno, que tinha um papel central no Leviatã. A apoteose destas tendências redundaria na perspectiva radical de Lukes. ${ }^{41}$ Neste caso, o poder se estende até o pensamento e a consciência do outro. Não se poderia imaginar um impulso mais soberano que o encapsulado por esta dívida com a problemática marxista da "falsa consciência". Nos conceitos em que se atribui um papel central à tecnologia, o mesmo projeto se repete devido a mudanças no controle forjado pelas inovações tecnológicas. Estas, a longo prazo e não obstante resistências, invariavelmente minam aquele potencial contido na ação autônoma de uma classe trabalhadora que no passado estava assentado na especialização e no conhecimento inerente ao controle dos processos de trabalho do artesão. A criação de trabalhos não autênticos torna-se a precursora e a explicação causal de ações condescentes quando a teoria teria preferido corpos revolucionários.

Projetos afins com o de Maquiavel tendem a relegar realizações globais e favorecer interpretações locais e contingenciais. É nesse sentido que o mundo "pósmoderno" de fluxo e desconcontinuidade de Foucault tem mais afinidades com o mundo moderno da Florença de Maquiavel. Ambos compartilham o enfoque analítico, bem como o fascínio por alianças inconstantes e instáveis, a preocupação com estratégias militares e a tendência de não acreditar em qualquer centro de poder único, originário e decisivo. Portanto, há uma distância entre essas perspectivas e o mundo mítico de uma ordem apresentado por Hobbes de modo tão positivo. As representações deste autor deixaram marcas na teoria moderna no tocante à insistência na natureza causal, atomista e mecânica das relações de poder, assim como na preocupação implícita com o centro originário do poder. No caso dos teóricos do processo trabalhista, isso é ex- 
presso através de uma conspiração para o controle pelo sujeito miticamente unificado do "capital". Os "trabalhadores", enquanto isso, perdem o poder de ação de outros modos do que o da reação ou da resistência.

Tanto Hobbes quanto Marx podem ser considerados os protótipos dos pensadores modernos. Ambos estavam comprometidos com noções de necessidade da ordem. Marx, obviamente, distinguia-se por sua concepção da probabilidade de que algum dia ela seria atingida na economia política existente, dadas as

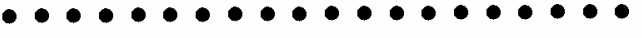

Em vez da tecnologia ser uma composição derivada a partir de uma nota neutra, seus ritmos interiores emanariam de uma nota de dominação e controle. ser considerado um pluralista distinto. ${ }^{45}$

$\mathrm{O}$ trabalho de Foucault tem se revelado o epicentro das transformações nas atuais concepções de poder. De uma concepção de poder mecanicista, centrada naqueles pressupostos que Hobbes procurou articular, recentemente passou-se para uma outra, mais receptiva à perspectiva estratégica inicialmente explorada por Maquiavel, subseqüentemente alargada num conceito "circulatório" do poder por Parsons ${ }^{46}$, e inexoravelmente atrelada à circulação do conhecimento através do discurso por Foucault. ${ }^{47}$ No certendências à desordem que prevaleciam na sua conceituação dos circuitos capitalistas de produção. Muitos marxistas subseqüentes explicaram a persistência desses circuitos em termos da hegemonia reinante que relações sociais e estatais capitalistas teriam supostamente assegurado. Ultimamente, essas explicações perderam considerável prestígio intelectual. Sofreram renovados ataques políticos na Europa Ocidental (o que, obviamente, não é novidade), estimulados pelos desenvolvimentos práticos no Leste Europeu, bem como pela onda considerável de críticas por parte da intelectualidade. Alguns desses ataques provinham da preocupação com os problemas empíricos envolvidos na busca do santo graal da hegemonia. ${ }^{42}$ Outros ataques provieram do mundo "pós-moderno", do "pósmarxismo" e do "pós-estruturalismo", um mundo no qual não sobrara espaço para a crença numa arquitetura para guiar a ação racional a ser seguida. Nenhuma fonte originária de ação habita o mundo pós-estruturalista, apenas uma série interminável de contingências. Embora isto seja mais evidente no trabalho de Laclau \& Mouffe ${ }^{43}$, alguns críticos, como Perry Anderson ${ }^{44}$ consideram que essas tendências já estavam implícitas em Foucault. Como já foi comentado em outra ocasião, é nesse sentido que Foucaut, tendo descentralizado o locus, ou seja a posição precisa, do poder, talvez devesse ne das últimas posições de Foucault, há uma preocupação constante com as relações entre poder e significado, ou, como ele prefere, entre poder e saber.

As concepções contemporâneas de significado observam sua existência na diferença entre os termos relacionais aos quais as representações correntes se sujeitam. No entanto, não há nenhum motivo para se esperar que as representações permanecerão contextual e historicamente estáveis mas, isto sim, para supor-se que elas venham a mudar. Desse modo, o poder estará implicado nas tentativas de fixar, ou separar e mudar, relações específicas de representação de significado. É uma virada que se desenvolveu mais explicitamente a partir da ontologia histórica de Foucault, derivada de algumas das subjetividades constituídas através de práticas de poder e saber. O saber usado para estruturar e fixar representações em formas históricas é uma realização do poder.

Pode parecer que estabelecendo-se a relação saber-poder como objeto de análise se está celebrando um relativismo no qual qualquer ponto fixo é dissolvido, como insistem alguns críticos de Foucault, entre eles Perry Anderson. Tratase, contudo, de uma reação extremada. $O$ que se dissolvem são as noções a presumirem uma posição transcendente qualquer que possa ser constituída fora das práticas discursivas. No seu interior, al-
42. ABERCROMBIE, N.S. \& TURNER, B.S. The dominant ideology thesis. Londres, Allen \& Unwin, 1980; CHAMBERLAIN, C.W. Class consciousness in Australia. Melbourne, Allen and Unwin, 1982.

43. LACLAU, E. \& MOUFFE, C. Op. cit.

44. ANDERSON, P. Imagined Communities: reflections on the origins and spread of nationalism. Londres, Verso, 1983.

45. CLEGG, S.R. Manufacturing Consent: changes in the labor process under capitalism. Chicago, University of Chicago Press, 1979.

46. PARSONS, T. Op. cit.

47. CLEGG, S.R. Framework of power. Op. cit. 
48. FOUCAULT, M. The History of Sexuality: an introduction. Harmonsworth, Peregrine, 1984. (Edição brasileira traduzida em três volumes por ALBUQUERQUE, Maria T. da Costa \& ALBUQUERQUE, J. A. História da sexualidade. Rio de Janeiro, Graal.)

49. WEEDON, C. Faminist practice and poststructuralist theory. Oxford, Blackwell, 1987, p. 123. gumas representações alcançarão, portanto, um poder muito maior do que outras, um poder que não é o efeito de um sujeito humano e suas volições, nem de uma estrutura que se satisfaz à revelia desse sujeito. São objetos de análise as próprias representações, ou seja, os modos discursivos fundamentais de se estabelecer as relações, sendo que elas têm um caráter histórico específico. A preocupação é basicamente com as estratégias do poder discursivo, sendo que a capacidade de realizar estratégias passa a ser considerada efeito de práticas distintas do binômio poder/saber a ascenderam na representação da subjetividade normal: por exemplo, formas de vigilância ou psiquiatria, que constituem o normal para uma penologia ou um saber médico; da "observação" e das regras destes ninguém escapa, seja o funcionário da prisão ou do serviço médico, seja o indivíduo confinado por razões médicas ou penais.

Em Vigiar e Punir, Foucault concebe o poder como uma técnica que alcança seus efeitos estratégicos através de seu caráter disciplinar. $\mathrm{O}$ autor considera os métodos de vigilância e avaliação de indivíduos, inicialmente desenvolvidos em instituições estatais como prisões, instrumentos efetivos, desenvolvidos para a arregimentação ordenadora de outros corpos igualmente dóceis. Ele sustenta que isso ocorre mesmo quando provocam resistência. No seu entender, esta serviria apenas para demonstrar a necessidade da disciplina que a provoca. E torna-se sujeita à disciplina, que pode justificar sua necessidade por não ser onipotente. Essas práticas disciplinares são amplamente disseminadas na escola, no exército e no antigo asilo, bem como, eventualmente, na fábrica capitalista. Tornam-se estratégicas na medida em que são constituições efetivas de poderes. Como formas de saber, agem através de sua própria ontogênese. E por serem saberes constituído não só em textos, mas também em práticas instrumentais e organizacionais definidas, são "práticas discursivas": saberes reproduzidos através de práticas possibilitadas pelos pressupostos que os compõem. Ademais, são saberes notadamente práticos: disciplinam o corpo, regulam a mente, e ordenam as emoções de tal maneira que a classificação, a hierarquia e a estratificação resultantes não são apenas a reprodução cega de urma ordem tradicional transcendente, como ocorria no feudalissmo. Geram uma nova base de ordem quanto ao valor produtivo dos indivíduos, à medida que são definidos por essas novas práticas disciplinares de poder.

Essas novas práticas disciplinares de poder, contudo, não devem ser entendidas como o efeito intencional de qualquer vontade, e menos ainda da vontade daquela tradicional condensação de poder que é o estado. "De um lado, não há um discurso do poder e, de outro, um outro discurso ao arrepio dele. Os discursos são elementos táticos ou blocos que operam no campo das relações de força; discursos diferentes $e$ mesmo contraditórios dentro da mesma estratégia podem coexistir; ou, pelo contrário, podem circular de uma estratégia para uma oposta sem mudar sua forma." 48

Seria um equívoco supor que existem, de um lado, interesses fixos e, de outro, discursos definidos representando-os. Por exemplo, o que antes era o "discurso capitalista" da privatização de desregulamentação pode ser postulado como o "discurso socialista" de um Ministro da Fazenda, como, por exemplo, o australiano Paul Keating. Pode-se dizer que a certeza dos interesses não é assegurada ao se proclamar o que deverá, no devido tempo, independentemente do seu conteúdo, tornar-se estereótipos políticos. "Os discursos não têm referência fixa em valores ou sistemas de moralidade particulares".49

Uma vez que não existe uma afinidade facultativa entre discurso, prática e interesses, o poder não pode ser entendido como uma "estratégia única, abrangente". 
O poder será uma rede mais ou menos estável ou uma rede inconstante de alianças estendidas sobre um terreno instável de práticas e interesses constituídos a partir de discursos. Pontos de resistência irão irromper em muitos locais na rede, $o$ que poderá resultar na ruptura de alianças, na constituição de reagrupamentos e na revisão das estratégias postuladas. Nessas formulações, o poder deve ser analisado na "multiplicidade de relações de força imanentes à esfera na qual operam e que constituem sua própria organização; (outrossim,) como o processo que, através de lutas $e$ confrontos incessantes, as transforma, as fortalece ou as inverte; como o suporte que essas relações de força encontram umas nas outras, formando assim uma cadeia ou um sistema ou, ao contrário, as disjunções $e$ as contradições que as insulam; $e$, finalmente, como as estratégias em que elas atuam, sendo que sua conformação geral ou sua cristalização institucional está corporificada no aparato estatal, na formulação das leis ou nas várias hegemonias sociais". 50

O mais importante da concepção de poder de Foucault é sua expressão inerentemente instável e mutável em redes e alianças. Em vez de uma visão monolítica do poder, seu enfoque filia-se às preocupações estratégicas de Maquiavel ou da noção de Gramsci ${ }^{51}$ de hegemonia como uma "guerra de manobras", na qual os pontos de resistência e fissura ocorreriam na linha de combate.

A concepção de poder de Foucault tenta romper definitivamente com a visão "mecanicista" e "soberana". Ele trata da criação de novas formas de poder social que se cristalizaram nos séculos XVII e XVIII, longe dos termos que hoje se tornaram relativamente convencionais na constituição do "poder" e quando a ele se dirige. $O$ que emerge durante esse período é uma "forma capilar" de poder, um poder que "se prolonga até a própria essência dos indivíduos, regime sináptico de poder, um regime para seu exercício de dentro do corpo social, em vez de a partir de cima".52

O "poder disciplinar" é um de dois conceitos muito distintos de poder que, conforme argumenta Foucault, teriam caracterizado a época "moderna" a partir do início do século XIX em diante. (O outro é o "bio-poder".) $O$ poder disciplinar visa a indivíduos ou grupos de indivíduos particulares. A peculiaridade da concepção de Foucault é apresentar uma perspectiva alternativa para as práticas de poder em seu questionamento histórico do poder disciplinar. Foucault sugere que, enquanto a trajetória moderna se fixou na mecânica dos objetos aparentes, um mundo real de práticas novas e diferentes estava surgindo, um mundo que foi ignorado por aquela concepção de poder. A partir desse ponto de vista, podemos começar a conceber a relação entre poder e tecnologia de maneira bem diferente do modo como está configurada, de acordo com a teoria do processo trabalhista. Recorde-se que na última, a tecnologia é o veículo do poder exercido para reafirmar o controle. Este é invariavelmente visto com um controle capitalista $e$, conseqüentemente, o veículo da tecnologia é encarado como um instrumento capitalista. ${ }^{53}$

A concepção de Foucault de poder disciplinar, o que teria sido desenvolvido para substituir o antigo poder soberano (do qual os preceitos de Maquiavel (1958) em $O$ Príncipe constituem um verdadeiro manual, embora um tanto esquemático), não é contraditória com a explicação de Weber. ${ }^{54}$ Tampouco, como já foi salientado em outras ocasióes ${ }^{55}$, a explicação de Weber do desenvolvimento da disciplina e do controle capitalista contradiz Foucault ou as recentes descrições do "processo trabalhista" da disciplina capitalista, desde que se desprezem certos pressupostos que consideram essa "disciplina" originária da engenhosidade dos capitalistas. (Clegg \& Dunkerley ${ }^{56}$ cometem este erro; ver também Marglin e Stone ${ }^{57}$; é interessante comparar com Rueschemeyer ${ }^{58}$, que chega a conclusões semelhantes seguindo um percurso diferente.)

O poder disciplinar, e particularmente sua "disciplina do tempo"59, certamente adveio dos mosteiros, confome argumenta Keiser.$^{60}$ No entanto, é igualmente certo que ele foi rapidamente adaptado no competitivo ambiente de aprendizado da industrialização capitalista nascente. Pode-se dizer que, de modo geral, houve um período de transição, de uma economia doméstica assentada no sistema de produção para uma fundamentada na fá-
50. FOCAULT, M. The history of sexuality. Op. cit. p.92.

51. GRAMSCI, A. Op. cit.

52. FOCAULT, M. Power/Knowledge: selected interviews and other writings 1972-1977. Brighton, Harvester Press, 1980. (Organização de GORDON, C.)

53. BRAVEMAN, H. Op. cit.; MARGLIN, S.A. Op. cit.

54. WEBER, M. From Max Weber: essays in sociology. Londres, Routledge and Kegan Paul, 1948. (Tradução e organização de GERTH, H. H. \& MILL, C.W.)

55. CLEGG, S.R.; BORENHAM, P. \& DOW G. Class, politics and the economy. Londres, Routledge and Kegan Paul, 1986; O'NEILL, J."The Disciplinary Society: from Weber to Foucault", British Journal of Sociology. $37(1): 42-60,1987$

56. CLEGG, S. R. \& DUNKERLY, D. Organization, class and control. Londres, Routledge and Kegan Paul, 1980.

57. MARGLIN, S.A. Op. cit.; STONE, K. Op. cit.

58. RUESCHEMEYER, D. Power and the division of labour. Cambridge, Polity Press, 1986.

59. THOMPSON, J. D. Op. cit.

60. KEISER, A."From Asceticism to Administration of Wealth: medieval monasteries and the pitfalis of rationalization", Organization Studies, 8(2):103-24, 1987. 
61. CLEGG, S. R. \& DUNKERLY, D. Op. cit.

\section{O'NEILL, J. Op. cit}

63. LASLETT, P. The world we have lost. Londres, Methuen, 1965, WALL, R.; ROBIN, J. \& LASLETT, P.(Org.) Family forms in historic Europe. Cambridge, Cambridge University Press, 1983.

64. LANDES, S. The Unbound Prometheus: technological change and industrial development in Western Europe from 1750 to the present. Cambridge, Cambridge University Press, 1969; MARGLIN, S.A. Op. cit.

\section{O'NEILL, J. Op. cit}

66. SMELSER, N. Social change in the industrial revolution. Chicago, University of Chicago Press, 1959.

67. BURAWOY, M. "Towards a Marxist Theory of the Labour Process: Braverman and $\mathrm{Be}-$ yond", Politics and Society. Op. cit.; CLAWSON, D. Bureaucracy and the Labor Process: the transformation of $U$. S. industry 1860-1920. Nova lorque, Monthly Review Press, 1980; EDWARDS, R. Contested Terrain: the transformation of the workplace in the twentieth century. Nova lorque, Basic Books, 1979; LITTLER,C.R. The development of the labour process in capital societies. Londres, Heinemann Educational Books, 1982

68. CLEGG, S. R. \& DUNKERLY, D. Op. cit.

69. GRAMSCI, A. Op. cit

70. WEBER, M. Op. cit. brica $^{61}$, embora seja certo que, como observou O'Neill'62, que, por sua vez, citou Laslett e Wall ${ }^{63}$, seria um mito considerar a família uma economia "natural". É evidente, contudo, que a cronologia do mundo foi transformada, muitas vezes numa só geração, de uma fundamentada em dias santos, festas locais e ritmos sazonais variáveis de produção agrícola para uma cronologia baseada nos ritmos da máquina industrial, do supervisor e da disciplina imposta pelo relógio da fábrica aplicados às "mãos" fabris. (Os trabalhadores literalmente eram "mãos" intercambiáveis recrutadas como tais.) $\mathrm{Na}$ ecologia competitiva dos regimes de produção do século XIX, as possibilidades de roubo, descaso e indisciplina no sistema de produção doméstica eram bem maiores do que o controle da fábrica ${ }^{64}$. A tônica desse controle fabril era o que Weber denominou "disciplina militar". Igualmente, como já foi tratado antes, esta disciplina tinha raízes tanto militares como monásticas, especialmente a subjugação do tempo individual à disciplina imposta externamente ligada ao tempo do patrão.

$\mathrm{O}^{\prime} \mathrm{Neill}^{65}$ observou, com base em Smel$\operatorname{ser}^{66}$, que certas mudanças tecnológicas como a máquina a vapor e o tear mecânico selaram a perda do controle por parte do trabalhador e a ascendência do mestre nas atividades ligadas à fiação. Essas mudanças foram gradualmente integradas nas atividades têxteis, com mulheres e crianças substituindo a antiga mão-deobra masculina do artesão, mão-de-obra esta cuja resistência foi persistente, violenta, política e prolongada. De fato, alguns escritores que focalizam a luta de classes, e em especial a produção ${ }^{67}$, julgam-na um campo de batalha, onde é travada a dialética entre o controle capitalista e a resistência do trabalhador, que é estruturalmente insolúvel, contanto que as relações capitalistas de produção sejam reproduzidas. É por este motivo que a dialética entre poder e resistência recebe uma localização estrutural precisa na teoria geral de Marx do capitalismo como relações de produção. A partir dessa perspectiva, desenvolveram-se teorias bem gerais a respeito da organização e do controle capitalista do processo trabalhista. ${ }^{68}$ A vertente de Foucault é uma correção útil ao tornar o processo muito menos instrumental que essas explicações supõem.

A concepção de poder disciplinar de Foucault, embora compatível com o enfoque marxista no tocante ao controle e à resistência no ambiente de trabalho capitalista, difere dela em dois aspectos importantes. Primeiramente, considera que o controle através da disciplina não teve inicialmente origem na fábrica, mas em várias instituições estatais. Os mestres capitalistas copiaram-no de supervisores das prisões e superintendentes de asilos. Em segundo lugar, não seria um controle funcionalmente orientado para a exploração capitalista, mas para a criação de corpos obedientes. Foucault trata detalhadamente da "incorporação" do poder. (Este enfoque não era inteiramente inédito, posto que Marx já estava ciente da violência praticada contra o corpo humano pela nova disciplina capitalista, como indicam muitas de suas passagens notadamente descritivas.) Gramsci ${ }^{69}$ também estava inteirado do impacto do sistema fordista nos corpos dos trabalhadores.

Weber ${ }^{70}$ também tinha consciência da "afinação" do aparato "psico-físico" produzido pelo "alcance ilimitado da disciplina", embora seu enfoque se concentrasse mais no papel que o protestantismo poderia desempenhar na produção de um aparato moralmente afinado e desejável.

De acordo com a abordagem ortodoxa do processo trabalhista, a relação entre tecnologia e poder ocorre de tal modo que a primeira é sempre mascarada pelo segundo, sendo que a máscara protegeria os interesses do capital. Quando se compara essa abordagem com o ponto de vista ortodoxo da "engenharia" a respeito da tecnologia, que a tem como um instrumento neutro e sem máscara, ela parece ser muito mais recomendável. Cada perspectiva, porém, tem falhas inerentes. Conforme a perspectiva ortodoxa da engenharia, o poder é invisível: simplesmente não existe. Conforme a perspectiva ortodoxa do processo trabalhista, ele penetra tudo e é totalmente previsível. Reveste a tecnologia de tal modo que a balança da soma zero sempre pende mais para o lado do capital. $O$ ardil do capital revela-se sob a superfície de qualquer cobertura que ele possa ter como ponto ar- 
quitetônico do fulcro que invariavelmente determina o resultado.

Há um importante antídoto para uma ou outra perspectiva na breve explanação das idéias de Foucault aqui expostas. Primeiro, são mínimas as certezas históricas que as explicações neo-marxistas fornecem no tocante ao poder do capital como centro do controle $e$ da inovação. $O$ isomorfismo institucional, mais do que franca inovação, pode caracterizar adequadamente $o$ desenvolvimento inicial do controle capitalista do processo trabalhista. Segundo, uma vez diminuída a importância do papel do capital como centro metafórico do controle, não se tem mais uma explicação a priori porque as organizações não podem ser concebidas como arenas de poder mais pluralísticas, em vez de territórios monádicos de controle. Recentes revisões da "teoria" do processo trabalhista que chegam ao ponto de admitir algo semelhante a essas possibilidades, como a de Armstrong ${ }^{71}$, por exemplo, que explica a competição inter-administrativa, simplesmente passam um verniz sobre as abordagens da "contingência estratégica" existentes, mas de uma maneira funcionalista e determinista, mes mo que disfarçada, conforme reconheceu Storey. ${ }^{72} \mathrm{~A}$ ardilosidade é deslocada do saber de capitalistas individuais dentro de suas organizações para o saber que diferentes profissões trans-organizacionais têm a oferecer como soluções para o modo de produção capitalista a padecer de crises recorrentes. O saber ainda é tratado de modo instrumentalista, como uma servente do poder tendo o status de um bem móvel. Ele não tem um papel próprio a desempenhar, nem autonomia. Uma instrumentalidade pura do saber carece de uma teoria do poder; aliás, uma instrumentalidade pura do poder também carece de uma teoria do saber.

Instrumentalidades puras do poder e do conhecimento têm uma posição correlata nos recentes debates em torno da relação entre a tecnologia e as organi- zações. De um lado, tem-se o instrumentalismo da perspectiva que privilegia o saber, um ponto de vista reconhecidamente "administrativo" do mundo no qual as mudanças tecnológicas simplesmente exigem adaptação social a novas formas de saber. De outro lado, tem-se o instrumentalismo da perspectiva que revela o poder, uma perspectiva reconhecidamente marxista na qual a mudança tecnológica é invariavelmente $o$ meio poderoso de instaurar o controle disfarçado de adaptação social a novas formas de saber. Cada ponto de vista é excessivamente unidimensional quanto à concepção de poder ou saber a forjá-los.

\section{A CONCEITUAÇÃO DO PODER ORGANIZACIONAL}

É necessária uma abordagem alternativa que não tenha sido seduzida pelas sirenas do conhecimento instrumental ou do poder instrumental. Urge uma síntese mais adequada do binômio poder/saber numa estrutura organizacional, para a qual a concepção de Foucault de "prática disciplinar" fornece uma chave inicial. ${ }^{73}$

O conceito de prática disciplinar visa a traduzir aquelas micro-técnicas de poder que se inscrevem e normalizam não apenas indivíduos, mas também corpos coletivos como organizações, através do cálculo dos modos de racionalidade analisados sob diferentes prismas de poder/saber. Qualquer organização formalmente eficiente via de regra tentará construir algumas práticas estratégicas gerais de disciplina. As organizações em busca desse objetivo dispõem de um estoque de técnicas disciplinares. Estão à disposição serviços de muitas organizações especializadas em vender técnicas disciplinares específicas, na forma de consultoria, assessoria ou subcontratação. Existem também os sedimentos resistentes de práticas anteriores, que foram seletivamente estruturadas sob regras de controle organizacional. ${ }^{74}$ Essas práticas não são apenas capa-
71. ARMSTRONG, P."Management Control Strategies and Inter-professional Competition: the cases of accountancy and personnel management". In KNIGHTS, D. \& WILMONTT, H. Managing the Labour Process. Aldershot, Gower, capítulo 2 1986.

\section{STOREY, J. Op. cit.}

73. CLEGG, S.R. Radical Revisions: power, discipline and organization. Op. cit

74. CLEGG, S.R. "Organization and Control", Administrative Science Quarterly. Op. cit. 
75. $\mathrm{COCH}$, L. \& FRENCH, J.T.P. "Overcoming resistance to change", Human relations. 1:512-32, 1948

76. HICKSON, D.J.; HININGS C.R.; LEE, C.A.; SCHNECK, R.E. \& PENNINGS, J.M. "A strategic contingencies theory of intra-organizational power", Administrative Science Quarterly. 16:216. 29,$1971 ; 19(1): 22-44$.

zes de atingir objetivos precisos, como também são reforçadas por sanções bastante generalizadas mas não menos efetivas, resultantes da estrutura do plano de carreira e do deslocamento ao longo dela. Essas práticas não são simplesmente coercitivas: não só punem e pró́bem; mas também, e principalmente, endossam e ensejam vontades obedientes e cons-

tituem formas de criatividade e produtividade aprovadas pela organização que se manifestam através de um processo tanto transitivo (através de externalidades autoritativas como regras, supervisores etc.) quanto intransitivo (através da aquisição de condutas consideradas apropriadas pela organização por parte de seus membros).

O elemento transitivo na produção da obediência disciplinada há muito vem sendo o foco central de teorias de organização, como evidencia a preocupação clássica com o papel da tecnologia na determinação da estrutura formal das organizações. Sem dúvida, essas representações têm um valor heurístico limitado quando usadas por pesquisadores. $\mathrm{Na}$ prática, no entanto, as estruturas relativas à autoridade raramente, se tanto, coincidem com a descrição prevista no programa da organizações. Muitos são os motivos: com o passar do tempo, as coisas mudam imperceptivelmente e de maneiras impossíveis de serem captadas por uma idealização estática; os membros da organização mudam de tal modo que "jogadores de poder" particularmente competentes podem tirar mais proveito de uma posição ou de uma tecnologia que um antecessor menos competente, $e$ assim por diante. Existe, porém, um motivo mais fundamental que esses eventos conjunturais para rejeitar-se essas descrições da estrutura formal das organizações. A resistência à autoridade e à disciplina está implícita nos processos intransitivos a constituir as práticas organizacionais disciplinares num território hierárquico.
Um elemento numa instância superior qualquer de uma organização complexa será apenas um retransmissor num fluxo complexo de autoridade que se desloca horizontal, vertical ou diagonalmente através das hierarquias de uma organização. Em termos ideais, em qualquer visão racionalista concebida por elites, planejadores e teóricos afins preocupados com organizações, tais retransmissores não deveriam apresentar resistência, nenhuma impedância, nenhum "problema de obediência". Isto está implícito na visão instrumental do saber na conceituação da tecnologia. Dificilmente, se tanto, este será o caso, como já sabem há muito tempo pesquisadores de organizações. ${ }^{75}$ A resistência, para prosseguir-se com a metáfora, tende a ser difusa. As autoridades, para usar-se o termo como um substantivo plural, poucas vezes, se tanto, estarão livres de resistência e retransmissores passivos. Pelo contrário, tratam-se de agentes ativos, interessados em assegurar a condição estratégica de sua conveniência.

Agências interessadas em maximizar sua capacidade estratégica devem tentar unir seu ponto de conexão com uma ou mais agências independentes para transformá-la num "ponto nodal necessário": um canal através do qual o tráfego entre elas possa ocorrer em termos que privilegiem a suposta agência estratégica. De outra forma, as tendências estratégicas não serão consumadas. E uma agência estratégica não será satisfatoriamente lograda. Destas observações derivaram os pontos centrais da teoria da contingência estratégica. ${ }^{76} \mathrm{~A}$ consecução de agências estratégicas exige disciplinar o arbítrio de outras agências. A articulação de interesses por agências estratégicas é, portanto, o meio e o fim de uma posição exclusiva em relação ao arbítrio das outras agências dispostas no território da organização. Ela precisa ser reproduzida para que as estruturas de poder existentes possam se reproduzir. De fato, sua repro- 
dução é um componente significativo dentre os fenômenos atinentes ao poder; e sua transformação, uma resistência efetiva a ele. Deveria ser evidente que essas reproduções são sempre pré-estruturadas, topografias unidimensionais nunca planas. Neste caso, a topografia será sempre o resultado de rivalidades presentes $\mathrm{e}$ anteriores. $\mathrm{Na}$ vida organizacional, esta estrutura de território deveria ser reproduzida por agências estratégicas, ou estará sujeita a transformações. A agência pode ser evidente em qualquer circuito numa rede de práticas. Em geral, mas não $\bullet \bullet \bullet \bullet \bullet \bullet \bullet \bullet \bullet \bullet \bullet \bullet \bullet \bullet \bullet \bullet \bullet \bullet \bullet \bullet$

De acordo com a abordagem ortodoxa do processo trabalhista, a relação entre tecnologia e poder ocorre de tal modo que a primeira é sempre mascarada pelo segundo, sendo que a máscara protegeria os interesses do capital. textuais que tanto permitem como restringem a ação. ${ }^{78}$ Essas regras podem ser consideradas a razão subjacente àqueles cálculos que as agências fazem rotineiramente nos contextos organizacionais. A ação só pode ser designada de uma forma ou de outra com base em regras que a identifiquem como tal. Essas regras nunca podem estar livres de um significado adicional ou ambígüo: são sempre indiciais com relação ao contexto dos intérpretes $\mathrm{e}$ das interpretações. Onde há regras há indexicalidade, conforme foi demonstrado por autores tão diversos como necessariamente, esses circuitos serão humanos: mas podem também ser departamentais ou inanimados. Uma conseqüência da posição assumida aqui é que locais organizacionais mais provavelmente serão locus de poderes polivalentes em vez de territórios mondádicos de controle total: terrenos contestados em vez de instituições totais. Barnes afirma que "manter o poder de arbitrio num grande número de rotinas demanda delegação. Mas para reter-se o máximo de arbítrio numa rotina particular é preciso delegar-se autoridade, não poder."77

A delegação de autoridade teoricamente mais poderosa depende do agente delegado agir "obedientemente". Caso contrário, será impossível dirigir as rotinas delegadas sem arbítrio. A "obediência" não pode ser garantida, até por força da complexidade e da contingência da agência, como uma conexão de cálculos. O arbítrio não precisa provocar dissensão: ele pode ser criativo, produtivo e reprodutivo em termos organizacionais. Não obstante, aumentar o poder de uma agência, que por sua vez também delega, significa autorizar outros delegados; autoridades delegadas não serão garantidamente locus de uma agência integralmente previsível e controlada, a menos que sejam servidores submissos. Importantes implicações derivam desta relação entre poder e arbítrio. $O$ poder sempre estará inscrito dentro de "regras de jogo" con-
Wittgenstein, Garfinkel, Clegg e Barnes ${ }^{79}$. As regras nunca podem prover sua própria interpretação. Questões de interpretação estão sempre implicadas nos processos pelos quais as agências exemplificam regras e atribuem significados a elas. "Regulamentar" é uma atividade. É desempenhada por uma agência como um processo constitutivo de fazer sentido pelo qual se estabelecem significados. Tanto as regras quanto os jogos necessariamente tendem a ser sujeitos a interpretações contestadoras, sendo que alguns jogadores não só atuam como tal, mas também como juízes, ou seja, recursos de poder. Conseqüentemente, quando regras são invocadas, há arbítrio. Portanto, não é apenas a corporificação, o poder trabalhista que é a fonte da resistência. $O$ poder e o controle da organização não estão implicados apenas no lapso entre a capacidade de trabalhar e sua realização, eles são inerentes à regulamentação do seu significado.

Aqui está-se frente ao paradoxo central do poder: aumenta-se o poder de uma organização, em princípio, pelo fato de essa organização delegar autoridade, a delegação de autoridade só pode ocorrer segundo regras, estas necessariamente pressupõem arbítrio, e este potencialmente fortalece os delegados. Quando introduz um saber novo e descontinua um saber existente nas organizações, a mudança tecnológica será o ponto central destas
77. BARNES, B. "On Authority and its Relationship to Power", in LAW, J. (Org.) Power, Action and Belief: a new sociology of knowledge? Londres, Routledge \& Kegan Paul, Sociological Review Monograph 32. pp.180-95, 1986.

78. CLEGG, S.R. Power, Rule and Domination: a critical and empirical understanding of power in sociological theory and organizational life. Londres, Routledge and Kegan Paul, 1975.

79. BARNES, B. "On authority and its relationship to power". Op. cit.; CLEGG, S.R. Power, Rule and Domination: a critical and empirical understanding of power in sociological theory and organizational life. Op. cit.; GARFINKEL, $H$. Studies in Ethnomethodology. Englewood Cliffs, N. J., Prentice Hall, 1967; WITTGENSTEIN, L. Philosophical Investigations. Oxford, Blackwell, 1968. (Tradução de ASCOMBE, G.E.); 
políticas paradoxais. Eventos e outros fatos devem ser considerados rotineiros $\mathrm{e}$ reversíveis para que a negociação permaneça um estado de coisas incomum e extraordinário. As rotinas surgem não tanto da proibição e da intervenção no estado das coisas, mas através da construção reconhecida desse estado de coisas, de modo que as agências subordinadas saibam o que devem fazer para minimizar quaisquer sanções que possam ser dirigidas a elas por superiores, ou por quaisquer outros elementos envolvidos nos circuitos de poder. Não só o poder se fundamenta no saber, ou seu controle exclusivo, ou seu acesso privilegiado. É também subordinação: como Barnes esclarece, tais agências "devem reconhecer que a ação apropriada resultante produzida é o que minimiza a coerção e a sanção recebida"80. É por este motivo que, onde quer que questões de tempo-espaço sejam necessárias para assegurar a ação de organizações, torna-se importante haver regras de práticas às quais os agentes possam se ater. A liberdade de arbítrio precisa ser disciplinada para que seja um retransmissor confiável. Não importa se isso seja conseguido através do que Foucault chama de prática "disciplinar", ou algum outro modelo. Pode ser a vigilância direta, a interiorização da auto-regulamentação profissional, um esquema de relatórios padronizado, interesses econômicos comuns, ou relatórios de clientes que funcionem como regras de atuação. $\mathrm{Na}$ ausência dessas regras, ou no caso de evasões ou do funcionamento precário dessas, as organizações são aconselhadas a confiar em agências, $o$ que não é nada bom, como bem sabia $\mathrm{Ma}$ quiavel.

O poder está envolvido na autoridade e é constituído por regras, a interpretação de regras precisa ser disciplinada e regulamentada para que novos poderes não sejam gerados e poderes existentes sejam transformados. Aliás, dada a indexabilidade inerente ao uso de regras, as coisas nunca serão inteiramente estáveis, geralmente exibirão tolerância à pressão, à tensão e à competição na constituição de regras cujos limites só podem ser conhecidos com certeza quando de rupturas indisciplinadas da regulamentação.

A resistência à disciplina será irremediável devido à constituição do binômio poder/regra como uma conexão de significados e interpretações que, devido à indexabilidade, está sempre aberta à reformulação. Isto é o que combina poder/saber na formulação de Foucault, de vez que, na sua forma mais difusa, o poder posiciona o indivíduo através da organização de práticas disciplinares que constituem as potencialidades, incapacidades e correlatos de formas específicas das agências. Dado o nível geral de difusão e aceitação da abordagem "institucional" nos estudos contemporâneos das organizações ${ }^{81}$, convém batizar a perspectiva aqui proposta como uma abordagem fundamentada em "poder/instituições". É a partir das estruturas institucionais de conhecimento disponíveis nas organizações e a sua volta que a multiplicidade de centros potenciais de poder nas organizações pode procurar fortalecer sua capacidade estratégica e, portanto, seu poder. Dentro da arena organizacional, agentes com estratégias variadas lutam para constituir as capacidades da organização em termos políticos que representem suas concepções de seus interesses. Assim fazendo, irão barganhar com quaisquer recursos que possam ser estratégicos. Os recursos podem estar tanto dentro quanto fora da arena organizacional. Não só existem recursos aguardando a oportunidade de serem ativados: mais apropriadamente, eles são constituídos em lutas que podem ser representadas discursivamente de maneiras diversas dentro do âmbito "racional" no sentido weberiano de racionalidade substantiva. Daí que possam ser denominados "modos de racionalidade".

Para que formas institucionais de saber-prática se tornem "estruturas de dominação", elas deverão articular-se em torno de valores culturais mais ou menos abstratos e poderão expressar-se através de ações situadas na organização e vocabulários de motivos. ${ }^{82}$ Estas são as maneiras normais de dar conta da ação (sendo que "dar conta" não está sendo empregado no sentido técnico do discurso da contabilidade). É através de tal prestação de contas que se pode reportar aos complexos de razões socialmente disponíveis e publicamente explicáveis com os quais se pode procurar justificar as ações organizacionais. Quando consideradas coletiva- 
mente, tais "racionalidades" podem ser vistas como "modos" de racionalidade. Não se deve buscar nessa designação nenhum pressuposto de "unidade" ou "coerência". É bem possível que as organizações, bem como os agentes dentro e em torno delas, possam construir racionalidades diversas e simultâneas que não sejam coerentes nem espacial nem temporalmente. Os modos de racionalidade são construídos a partir de concepções disponíveis localmente que embutiram a ação econômica. Eles podem ser derivados de costumes ou práticas locais, uma vez que foram moldadas pela cultura ou pela estrutura institucional de vocabulários de motivos à disposição.

\section{PODER E TECNOLOGIA: OS DEBATES SOBRE A "ESPECIALIZAÇÃO FLEXÍVEL"}

Da perspectiva de poder adotada aqui, não há um motivo apriorístico para que poder e tecnologia devessem ser implicados de determinadas maneiras em sua inter-relação. Nenhum modo necessário de racionalidade de "des-especialização" ou neutralidade os une. A natureza desta relação provavelmente é muito mais aberta e indeterminada, pelo menos em princípio. A diferença ocorrida com a adoção dessa estrutura fica clara quando se consideram alguns dos recentes debates sobre a relação entre poder e a "nova" tecnologia associada à especialização flexível em práticas de trabalho. Isto porque a natureza das novas práticas de trabalho estão estreitamente vinculadas à introdução de novas tecnologias. Os diferentes tipos de práticas de trabalho são maneiras formalmente diferentes de ordenar as relações poder/arbítrio em organizações de acordo com diferentes estruturas institucionais de critérios de regras.

Critica-se muito a idéia de que os sistemas flexíveis de produção podem estar introduzindo uma nova era de organização. À medida que essas críticas atingem os argumentos determinísticos e ins- trumentalistas em mente, elas estão certas. Mas, infelizmente, de modo geral usam um instrumento inadequado, cujos efeitos são igualmente determinísticos. Pode-se argumentar que, em condições ambientais apropriadas, onde as estruturas institucionais restringem o livre-arbítrio administrativo e o funcionamento do mercado de trabalho, esses sistemas podem ser o veículo para a formação de especialidades e a participação da força de trabalho das organizações, em vez da introdução de novas tecnologias que levem à "des-especialização" dos traba-

lhadores. Ou não.

Há três posturas amplas entre os debates sobre os sistemas flexíveis de produção. São elas o neo-romantismo, o neoadministrativismo e a crítica neo-marxista. As duas últimas já foram consideradas, respectivamente, instrumentalismos de administrativismo e poder. Enquanto que o administrativismo postula uma instrumentalidade neutra e o marxismo, uma instrumentalidade negativa, uma terceira posição advoga um instrumentalismo positivo. É a neo-romântica, caracterizada pelo triunfo do otimismo em detrimento do realismo. Uma quarta posição está fundamentada nos termos de poder delineados acima, e que os vincula à visão das organizações como arenas em cujo interior, bem como à sua volta, várias formas de saber são utilizadas pelas agências que buscam, com variados graus de eficácia, assegurar o que consideram ser seus interesses. Ao contrário de outras posições, ela não parte de nenhum pressuposto apriorístico a respeito da tecnologia da produção flexível se ela é ou não "uma coisa boa"; em vez disso, procura analisar como e através de que variáveis, configurações do binômio poder/instituições estruturam instâncias empíricas.

\section{O neo-romantismo}

$\mathrm{O}$ argumento neo-romântico deriva da contribuição de Piore \& Sabel ${ }^{83}$, que insis-
83. PIORE, M.J.\& SABEL, C.F. The Second Industrial Divide: possibilities for prosperity, Nova lorque, Basic Books 1984. 
84. SMITH, C. "Flexible specialization, automation and mass production", Work, Employment and Society, 3(2):203-20, 1989.

85. SABEL, C.F. Work and politics. Cambridge, Cambridge University Press, 1982

86.PIORE, M.J.\& SABEL, C.F. Op. cit.

87. BELL, D. The Coming of Post Industrial Society. Harmondsworth, Penguin, 1974. tem estarmos num divisor crítico na história da humanidade, e que os aspectos utópicos da comunidade, perdidos no século XIX com a dissolução do trabalho artesanal da indústria doméstica, agora podem ser recuperados. $O$ romantismo reside nesta visão retrospectiva. Em essência, esta teoria está voltada para o consumo. Ela contrapõe o regime modernista de consumo de massa através de mercados padronizados, fundamentado em burocracias da produção em massa organizadas em torno de relações de baixa confiança, com algumas mudanças iniciadas em fins da década de 70 . Nessa época, a conjunção de vários fatores tornou impraticável a primazia absoluta do antigo regime de produção. Dentre esses fatores, foram lembradas a recessão ininterrupta depois de 1970 e a crescente competição do Japão e outros países de industrialização recente. Foi especialmente a partir do Japão que as novas idéias ganharam legitimidade.

$O$ que estava sendo questionado era o caráter de "massa", tanto da produção quanto do consumo, no sistema antes dominante de organizar a ação econômica. De um lado, os produtores japoneses pareciam estar superando outros produtores do Ocidente com sua ênfase na alta qualidade e na diferenciação dos produtos; de outro, o Ocidente parecia incapaz de responder competitivamente na medida em que permanecia preso a um sistema de produção em massa, baixa margem de lucro e padronização dos produtos. Ademais, alguns aspectos do próprio sistema de produção em massa afiguravam-se cada vez mais disfuncionais, notadamente os custos relativos a inventários e retificação de defeitos.

De acordo com a explicação de Piore \& Sabel, as mudanças de mercado causadas pela competição dos produtos japoneses são a chave para compreender-se a produção flexível. Um mercado mais diferenciado e orientado para o consumidor significou que as organizações flexíveis teriam uma vantagem competitiva. $O$ termo "especialização flexível" foi, portanto, introduzido para caracterizar tais organizações. O caráter "flexível" refere-se à reestruturação do mercado de trabalho e do processo de trabalho, enquanto que o caráter de "especialização" refere-se à predominância de nichos, ou mercados e mercadologias especializados, em oposição aos mercados de massa. É o impulso destes últimos que está exigindo uma resposta dos primeiros. $\mathrm{Mu}$ danças para um consumo mais diferenciado causam mudanças na produção bem longe das organizações assentadas no controle administrativo rígido através da vigilância, a "des-especialização" e a mecanização. ${ }^{84}$ Como Sabel ${ }^{85}$ propôs inicialmente, essas mudanças visariam a um novo tipo de "indústria caseira altamente tecnológica", na qual formas artesanais de produção seriam envolvidas por novas formas de tecnologia, estimuladas por iniciativas estatais locais. Os modelos do tipo Benetton de Emilia-Romagna são o caso paradigmático. Em colaboração com Piore 86 , isto é um pouco ampliado para incluir não só a indústria caseira altamente tecnológica, como também para reestruturar a indústria de produção em massa que está adotando novas tecnologias e práticas com base em novas formas de saber. Este elemento da teoria lembra algumas das considerações de Bell ${ }^{87}$ a respeito da sociedade "pós-industrial". Smith aponta um deslocamento do romantismo utópico de uma "indústria caseira altamente tecnológica" antevisto por Piore para um romantismo mais contemporâneo na adoção de uma tecnologia de "comunidade corporativa e solidariedade" descrita em Piore e Sabel. Neste último trabalho, não se enfocam pequenos negócios e produção artesanal, mas as relações industriais e da engenharia, além da reestruturação da produção das empresas Boeing, General Electric, General Motors e Ford com vistas a fazerem frente ao desafio japonês. No cerne dessa re- 
estruturação encontra-se a especialização flexível a permitir um novo organicismo à semelhança de um refúgio seguro no mundo até então cruel das grandes organizações. Eles propõem que a organização está cada vez mais próxima de ser caracterizada por uma produção flexível e sensível ao mercado, baseada em especializações e tecnologias generalizantes, em vez de outras altamente diferenciadas. Posteriormente, Katz \& Sabel ${ }^{88}$ e Piore argumentaram que o principal obstáculo para a realização deste novo organicismo são as instituições trabalhistas que não mudaram para acomodar os novos sistemas de produção, como ocorreu na Alemanha Ocidental e no Japão. Smith ${ }^{89}$ sugere que a síntese dos interesses entre trabalhador e empregador na tipologia da "especialização flexível" se resolve em favor dos empregadores. Assim como Pollert ${ }^{90}$, Smith é cético quanto à possibilidade de haver uma tendência no mercado para a diversificação de produtos nas indústrias de produção em massa como, por exemplo, a alimentícia.

$O$ determinismo do argumento neo-romântico está em considerar que a organização a determinar o mercado do produto está se reestruturando e que a difusāo da especilização é flexível.

\section{O neo-administrativismo}

Os autores neo-administrativistas são em sua maioria ingleses e caracterizamse pelo trabalho de pensadores como Cross $^{91}$ e do Relatório de 1986 do National Economic Development Office (NEDO). Enquanto que os neo-românticos tendem a enfatizar as forças do consumo e o mercado de produção e os neomarxistas, a relevar as forças e as relações associadas à produção, a escola neo-administrativa considera tanto a produção quanto o consumo como forças a promoverem a flexibilização.

A ênfase no consumo é semelhante à dada por Piore \& Sabel. Para terem a flexibilidade ao responderem às condições mutantes do mercado, as organizaçōes tiveram que desenvolver um grupo de empregados empenhados e flexíveis, segundo o modelo da "japonização". Conseqüentemente, desenvolveu-se um sistema de garantia empregatícia para os elementos estratégicos contingenciais da força de trabalho e, simultaneamente, ocorreu a marginalização de outros trabalhadores, transformados que foram em mão-de-obra indefinida ou de tempo parcial; em sua maioria, essa mão-de-obra era feminina. ${ }^{92} \mathrm{O}$ grupo dos trabalhadores selecionados desenvolvem especializações específicas à empresa; como corolário, os empregadores investem pesadamente em treinamentos que eles protegem como um investimento ao oferecerem a esses empregados segurança, retreinamento e toda oportunidade de integração na cultura da organização. Por sua vez, os trabalhadores marginalizados em geral não têm especialização nem gozam de nenhum dos benefícios concedidos aos trabalhadores do setor primário. A administraçāo está simplesmente respondendo aos novos padrões de escolha racional no mercado ao mudarem suas escolhas racionais quanto ao arranjo da organização e das relações de produção.

A versão mais determinista em termos tecnológicos do argumento administrativista até mesmo nega à organização a capacidade de administrar, enquanto outras pelo menos concedem alguma escolha "estratégica". A tecnologia determina a estrutura das organizações, e à administração resta pouco ou nada a fazer exceto talvez responder aos ditames das contingências. Para Blauner ${ }^{93}$, freqüentemente rotulado de determinista tecnológico, o fator mais importante a dar a uma indústria seu caráter distintivo seria sua tecnologia, que estabeleceria os limites da organização do trabalho. Child ${ }^{94}$ argumentou que a relação entre tecnologia e estrutura é correlacional, mas não causal. Argyris ${ }^{95}$ concorda com Child quando argumenta que existem escolhas na determinaçāo da estrutura da organização, e que as escolhas irão refletir os interesses daqueles com poder para fazê-las. Child estabeleceu um argumento ao focalizar a açāo social no processo de trabalho, o próprio trabalho, o planejamento e a ordenação do trabalho e seu significado para as pessoas envolvidas. Ultimamente, Child concentrou-se no propósito estratégico da administração na mudança tecnológica e observou que os administradores normalmente têm vários objetivos em mente quando introduzem novas tecnologias. A ênfase num desses objeti-
88. KATZ, H.C. \& SABEL, C.F. "Industrial relations and industrial adjustments in the car industry". Industrial Relations. 24(2): 295-315, 1985.

89. SMITH, C. Op. cit.

90. POLLERT, A. "Dismantling Flexibility", Capital and Class. 34(1):42-75, 1988

91. CROSS, M. Towards the Flexible Craftsman. Londres, Technical Change Centre, 1985.

92. LEVER-TRACY, C. "The Flexibility Debate: part time work", Labour and industry. 1(2):210-241, 1988.

93. BLAUNER, R. Alienation and freedom. Chicago, University of Chicago Press, 1964

94. CHILD, J. "Strategies of control and organization behaviour", Administrative Science Quarterly. 18.1-17, 1973.

95. ARGYRIS, C. The applicability of organizational sociology. Cambridge, Cambridge University Press, 1972. 
96. PALLOIX, C."The Labour Process: from Fordism to NeoFordism", in The labour process and class struggle. Londres, Stage 1, pp. 46-67, 1976

97. PIORE, M. \& SABEL, C.F Op. cit.

98. CORIAT, B. "The Restructuring of the Assembly Line: a new economy of time and control", Capital and Class. 11: 3443, 1980.

99. AGLIETTA, M.A Theory of Capitalist Regulation. Londres, New Left Books, 1979.

100. WILLIAMS, K; CUTLER A.; WILLIAMS, J. \& HASLAM, C. "The end of mass production?", Economy and Society. 16(3):405-39, 1987; BRAMBLE T. "The Flexibility Debate: industrial relations and new management production practices". Labour and Industry, 1(2):187 109, 1988; HYMAN, R. "Flexible Specialization: miracle or myth?", in HYMAN, R. \& STREECK, W.(Org.). Trade unions, technology and industrial democracy. Oxford, Blackwell, pp.4860, 1988; POLLERT, A. Op. cit

101. CRESSEY, P. Participation Review. Luxemburgo, European Foundation for the Improvement of Living and Working Conditions, 1987; DANIEL, W. Work place industrial relations and technical change. Prances Pinter, 1987; DEERY, S. "Determinants of trade union influence over technological change", New Technology and Employment 4(2): 117-130, 1989; DOGSON M. \& MARTIN, R. "Trade Union Politics on New Technology, facing the challenge of the 1980's", New Technology. Work and Employment. 2(1), 1987 WILLMAN, P. "New Technology and Industrial Relations: a review of the literature". Department of Employment, 1986.

102. DEERY, S. "Determinants of trade union influence over technological change". New Technology and Employment. 4(2): 117-130, 1989. vos pode variar de acordo com as prioridades e os propósitos da organização e o contexto no qual ela opera. Esta é a visão clássica da contingência, que hoje é tida como o melhor da teoria administrativa contemporânea. Ela certamente não ignora a política nem supõe que o processo de mudança tecnológica é inevitável e politicamente neutro. Ela tem afinidades com as posições neo-marxistas de autores mais críticos do que as versões desenvolvidas por Child.

\section{Críticas neo-marxistas no debate sobre a especialização flexível}

A crítica neo-marxista combina temas que encontraram expressão no debate do "processo trabalhista" com o debate mais recente em torno da especialização flexível. Com isso, ela agregou um grande número de contribuições dos teóricos franceses da escola da "regulação", notadamente a contribuição seminal de Palloix. ${ }^{96}$ Desta perspectiva, os fenômenos que autores como Piore \& Sabel ${ }^{97}$ estudaram não representam um "grande divisor" entre épocas mas, isto sim, mudanças de ênfase bastante significativas, não obstante dentro da mesma estrutura. É por este motivo que eles se referem ao neo-fordismo e não ao pós-fordismo. Os fenômenos do trabalho mais coletivo e do aumento da especialização são vistos como novas técnicas de controle, sendo que as prerrogativas administrativas não são questionadas e a autonomia do grupo de trabalho passa a ser uma internalização por parte da coletividade dos trabalhadores do que até então tinha sido vigilância externa. ${ }^{98}$ Esses autores sugerem que os interesses da companhia prevalecerão em qualquer reestruturação.

Temas antigos e familiares sobre a incorporação de trabalhadores, sua integração na organização e a ardilosidade do capital ao introduzir novas tecnologias para aumentar a exploração intensa de força de trabalho: estes são os temas tratados pela literatura neo-marxista a respeito das novas formas de produção flexível. Para escritores como Áglietta99, do ponto de vista capitalista, o neo-fordismo representa uma solução capitalista para o maior problema das administrações científicas. O problema é como reconquistar, reutilizar e voltar a controlar os trabalhadores formalmente excluídos, mas tacitamente aproveitáveis pelo saber da processo produtivo, e usá-lo para ampliar a reestruturação capitalista.

Para a escola neo-marxista, a explicação focaliza, o que não é surpreendente, as relações de produção, e não os mercados produtivos. $\mathrm{O}$ neo-fordismo resolve as contradições que o regime fordista anterior desenvolveu, mas foi incapaz de solucionar. A principal contradição era que o regime fordista tinha atingido os limites de sua capacidade de aumentar a produtividade. Sem reintegrar de alguma maneira o consentimento e o conhecimento ativo dos trabalhadores no processo produtivo, o fordismo deparou com o obstáculo inscrito em seu próprio projeto. Isto ficou claro à medida que a produtividade da mão-de-obra começou a diminuir nas décadas de 60 e 70 , quando o prolongado crescimento econômico do pós-guerra esmoreceu. Somente nos países que desenvolveram novas formas de regime de acumulação, baseadas na crescente participação dos trabalhadores, notadamente no Japão, foi que a produtividade aumentou. Isto apontou o caminho para um novo regime de acumulação que afetou a resolução temporária das contradições do capitalismo surgidas no regime anterior. No seu cerne, havia a tecnologia material das novas forças produtivas, e a tecnologia de produção flexível como, por exemplo, a permitida pelos sistemas CAD/CAM (Computer Aided Design/ Computer Aided Manufacturing), assim como novas relações de produção que incorporavam o trabalhador em vez de aliená-lo.

$\mathrm{Na}$ literatura neo-marxista surgiram algumas críticas à idéia de que a organização, em virtude da especialização flexível, não oferece nada de essencialmente nóvel. Entre elas, destacam-se as contribuições de Williams, Cutler, Williams \& Haslam, Pollert, Bramble e Hyman. ${ }^{100}$ Há um consenso praticamente universal de que os sindicatos exerceram pequena influência no processo de decisão da tecnologia e da nova organização trabalhista adotadas. ${ }^{101}$ Como observa Deery ${ }^{102}$, houve algumas exceções onde os sindicatos foram capazes de negociar acordos que garantissem empregos e protegessem os 
níveis de especialização, mas mesmo a provisão em direitos estatutários fez pouco para garantir uma participação efetiva na introdução de novas tecnologias ${ }^{103}$. Os acordos relativos à tecnologia realizados na Dinamarca e na Suécia não concederam aos sindicatos nenhuma possibilidade de influenciar substancialmente na introdução e no uso de novas tecnologias. A principal vantagem foi terem imposto aos empregadores a obrigação de informar os empregados qualquer mudança tecnológica importante "no devido tempo", ou seja, antes que ela ocorra. ${ }^{104}$ Foi aprovada na Suécia que, contudo, não limita significativamente o direito administrativo de administrar. Poucas são as vezes que os sindicatos se envolvem seriamente nas decisões das organizações. ${ }^{105}$ Conforme observou Manwaring, os "sindicatos não foram bem sucedidos em garantir uma parcela dos beneficios provenientes das novas tecnologias". 106 Eventuais influências em mudanças tecnológicas resultaram de ações furtivas. ${ }^{107}$

Embora os administradores afirmem que consideram a participação "complementar" a seu direito de administrar, e não um desafio a seu poder ${ }^{108}$, eles desejam manter a iniciativa nas decisões e total arbítrio nas questões. Participação significa dizer "aos trabalhadores quais seriam as necessidades da empresa (e) persuadi-los a aceitar as novas tecnologias $e$ as novas práticas de trabalho que as acompanham". ${ }^{109} \mathrm{Os}$ argumentos neo-marxistas alegam que a administração não tentou maximizar o arbítrio e minimizar o controle, confiar nos julgamentos dos trabalhadores, manter expectativas positivas quanto à confiabilidade do trabalhador ou permitir a auto-organização. Os programas de mudanças técnicas enfatizam educar os trabalhadores, e não envolvê-los na decisão antes que ela seja tomada - esta é uma prerrogativa da administração. Tudo está sob o controle administrativo. Com quem está o arbítrio durante a mudança técnica? Certamente não com os trabalhadores
- argumentaria a administração. Por que os administradores haveriam de experimentar técnicas de controle desconhecidas, que podem ser ameaçadoras e problemáticas, e podem levar à deterioração do poder e à redução do controle que eles já detêm? Pollert ${ }^{110}$, por exemplo, assim como Skaiken ${ }^{111}$ nos Estados Unidos e Bramble $^{112}$ na Austrália, argumenta que, na prática (e não na teoria ideológica de autores como Piore \& Sabel $^{113}$, a tecnologia do microprocessamento está sendo usada para a "desespecialização" a pretexto da implantação de flexibilidade. A tendência é julgar a nova tecnologia a serviço de alguns velhos objetivos de exploração de classe.

No cerne dessas críticas neo-marxistas há a grave suspeita de que a especialização flexível seria simplesmente um outro instrumento do capital para explorar ainda mais os trabalhadores. Isto se daria com a aceleração do ritmo do trabalho e sua intensificação, o que aumenta a tensão mental e o desgaste físico relacionados ao trabalho; com a criação de uma nova aristocracia de trabalhadores qualificados e uma crescente periferia de trabalhadores sem especialização, que não recebem nenhuma das compensações em termos de confiança, poder e responsabilidade desfrutadas por essa nova aristocracia. Dessa forma, o movimento sindical está dividido como a força de trabalho, entre os que estão preparados para trilhar a rota "realista e nova" da flexibilidade e os que podem apenas representar trabalhadores cujas posições acham-se em relativo declínio, porque não querem ou não são capazes de fazer acordos industriais unilaterais ou de tomarem a forma de sindicatos nos moldes das empresas. Os críticos condenam sobretudo o "otimismo tecnocrático" mas freqüentemente, ao fazerem isso, acabam "recaindo nos velhos bordões ideológicos", como sugerem Badham \& Matthews. ${ }^{114}$
103. CRESSEY, P. "The Restructuring of the Assembly Line: a new economy of time and control". Capital and Class. 11:3443.

104. BANSLER, J. "Trade unions and alternative technology in Scandinavia". New Technology, Work and Employment. 2: 9298, outono 1989.

105. WILSON, D.; BUTLER, R.; CRAY, D.; HICKSON, D. \& MALLORY, G. "The limits of trade union power in organizational decision making". British Journal of Industrial Relations. 20(3), 1983.

106. MANWARING, T. "The trade union response to new technology". Industrial Relations Journal. 12(4), julho 1981.

107. MOORE, R. \& LEVIE, H. "New technology and the unions", in FORESTER, T.(Org.) The Information Technology Revolution. Blackwell, 1985

108. CRESSEY, P.; ELDRIDGE, J.; McINNES, J. \& NORRIS, G. Industrial Democracy and Participation: a scottish survey. Research Paper $n^{\circ} 28$, Department of Employment, 1981.

109. EDWARDS, P. K. Op. cit.

110. POLLERT, A. Op. cit.

111. SHAIKEN, H.; HERZENBERG, S. \& KUHN,S. "The work process under more flexible production", Industrial Relations. 25 (2): 167-83, 1986

112. BRAMBLE, T. Op. Cit.

113. PIORE, M.J. Z\& SABEL, C.F. Op. cit.

114. BADHAM, R. \& MATTHEWS, J. "The production systems debate". Labour and Industry. 2(2):194-246, 1989. 


\section{A PRODUCÃO FLEXÍVEL NA CONJUNÇÃOO PODER/NSTITUIÇÕES}

Hoje, na teoria da organização, prevalesce o amplo reconhecimento de que existe mais de uma maneira de se lograr uma boa adequação entre tecnologia e estrutura, e de que a escolha pode ser feita objetivando-se tan-

to o poder quanto a eficiência. ${ }^{115} \mathrm{~A}$ interseção entre fatores institucionais e o poder na delimitação dessas escolhas fica bem clara em trabalhos comparativos sobre os "sistemas de produção flexíveis" (FMS, do inglês fle-

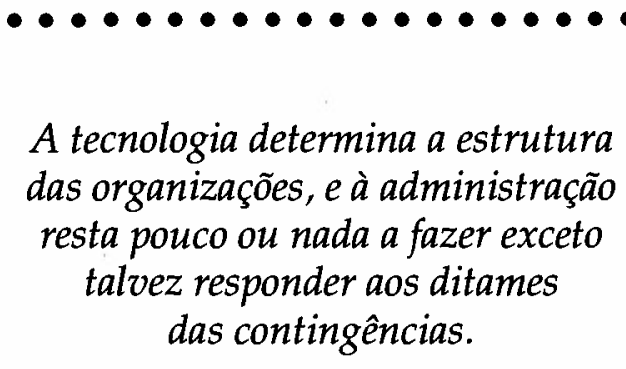

- zir grandes volumes de uma ampla variedade de peças. O número médio de peças produzidas com o sistema de produção flexível nos Estados Unidos era 10; no Japão, 93. O volume anual por peça era 1.727 nos Estados Unidos e 258 no Japão. Com efeito, as corporações norte-americanas estavam usando o sistema de produção flexivel para produzir peças em massa".117

Nos Estados Unidos, o sistema de produção flexível era usado para favorecer a "des-especialização" dos trabalhadores, aumentar o poder relativo da administração e produzir grandes lotes de um produto padronizado. Child ${ }^{118}$ enfatizou que é improvável que o sistema de produção flexível possa gerar muita diferença organizacional em casos como a produção de grandes lotes padronizados, particularmente, pode-se acrescentar, quando o produto tem baixa margem de lucro. Só nos casos em que ocorre variação no produto pode-se prever mudanças significativas na estrutura organizacional. A questão crucial a ser considerada seria se mudanças de produtos e métodos de produção são ou não imprevisíveis, como sugeriram Badham \& Mattews. ${ }^{119}$ Estudos a respeito realizados por Shaiken ${ }^{120}$ nos Estados Unidos demonstraram que a nova tecnologia tem sido usada para diminuir a autonomia e a responsabilidade no planejamento dos trabalhadores de oficinas. No Japão, a situação é bem diferente, muito embora a tecnologia seja a mesma. Lá a tecnologia foi usada para fornecer novas especializações, e não para tirá-las; foi atrelada a equipes de trabalho de múltiplos níveis e múltiplas especializações; e permitiu que operadores de oficinas se envolvessem ao realizarem programações rotineiras de computador. Em resumo, foi usada para transformar os trabalhadores em "trabalhadores pensantes"121. As razões dessas diferenças deveriam ser óbvias. Kenney \& Florida expõem-nas com bastante clareza: "A resposta do Japão à reestruturação foi determinada em grande parte pelos arranjos organizacionais e institucionais que inici- 
almente surgiram na produção, o que gerou o espaço social e a flexibilidade na qual a inovação organizacional poderia ocorrer. A organização industrial japonesa abriu caminho para uma sintese entre produção e inovação, $e$ para a integração de novas tecnologias na produção." 122

O ponto analítico é óbvio. A tecnologia, como qualquer outra contingência organizacional, não irá determinar nada necessariamente. $O$ determinismo tecnológico tem servido como um suporte para os estudos sobre a organização, mas chegou a hora de aposentá-lo. $O$ tema foi esgotado, e restou muito pouco, especialmente após as recentes discussões sobre os "novos sistemas de produção". O que está em xeque são contingências situacionais e sua construção em modos de racionalidade específicos. Conforme Badham \& Matthews, essas contingências não terão efeitos determinados e previsíveis na organização do trabalho, mesmo quando parecem inequivocamente fortalecer os trabalhadores: "Por exemplo, $o$ controle efetivo de planos de produção e a escala do trabalho em geral, saúde e segurança, formas de interação social (condições de trabalho) ou de pagamento, a garantia de emprego e planos de carreira (condições de contratação) pode ser reduzido com uma diminuição do poder de barganha coletivo ou individual dos trabalhadores - por força de vários motivos: aumento do desemprego, falta de um mercado de trabalho externo para as especializações recém adquiridas, declínio na força competitiva da empresa, uso da nova tecnologia para substituir especializações dos trabalhadores, redução das garantias legislativas, aumento da força da administração, queda no quadro de associados, fortalecimento do poder financeiro e organizacional dos sindicatos, ou mudanças nos partidos políticos ou na política. "123

A maneira como os elementos da prática organizacional como a tecnologia são efetivamente urdidos em modos de racionalidade depende da estrutura das instituições e do poder. Um segundo caso poderá esclarecer a questão. Sorge et alii estudaram a adoção de máquinas operatrizes controladas por computadores num grupo de organizações na Inglaterra e na Alemanha Ocidental. Eles compararam as organizações e descobriram que algumas das diferenças no modo como essas máquinas geravam a polarização ou a eqüidade das especializações poderiam ser atribuídas a contingências da organização, como a produção em lotes e o tamanho da firma. Havia diferenças mais amplas, contudo, que não correspondiam a essas contigências. Na Alemanha, num contexto de envolvimentos desde institucional até de determinação coordenada, máquinas controladas por computadores eram usadas de tal maneira que desenvolveram um foco comum de equipes entre supervisores, encarregados, trabalhadores e planejadores, constituindo uma verdadeira préfiguração pós-moderna. $\mathrm{Na}$ Inglaterra ocorreu o oposto: elas eram usadas de maneira a manter a autonomia dos grupos de departamentos e trabalhadores. Como sugeriram Sorge \& Streeck, é preciso um "conceito para a maneira como uma sociedade ou uma economia é povoada por tipos técnicos e organizacionais, e como esta população muda com o tempo." 125

Com base nas explicações e nas fontes originais disponíveis em inglês, pode parecer que o ponto de vista defendido por Sorge \& Streeck está efetivamente melhor desenvolvido na literatura da Alemanha Ocidental, particularmente pelo fato de que ele se desenvolveu em torno das contribuições de Kern \& Schumann. ${ }^{126}$ Explicações úteis em inglês incluem Kern \& Schumann, Littek \& Heissig, Hoss e Campbell. ${ }^{127} \mathrm{O}$ último é o mais detalhado. A Alemanha Ocidental revelou-se um território fértil para um grande número de estudos baseados nas idéias da escola de Aix a respeito da importância das diferenças nacionais e institucionais na estruturação das organizações, com especial ênfase nos sistemas de educação e treinamento e nas relações industriais na configuração das contingências organizacionais da força de trabalho. ${ }^{128}$ Ademais, nas contribuições de Kern \& Schumann, consta uma discussão empiricamente bem fundamentada do debate em torno da flexibilidade.

Inicialmente concebido como um estudo que daria continuidade a um trabalho feito uma década antes sobre a "des-especialização" em indústrias da Alemanha Ocidental, o livro de Kern \& Schumann Das Ende der Arbeitsteilung?, que poderia ser traduzido como "O Fim da Divisão de Trabalho?", descobriu que nas indústrias
122. KENNEY, M. \& FLORIDA, R. Op. cit.

123. BADHAM, R. \& MATTHEWS, J. Op. Cit.

124. SORGE, A; HARTMANN, G.; WARNER, M. \& NICHOLS, I. Microelectronics and Manpower in Manufacturing. Aldershot, Gower, 1983

125. SORGE, A. et alii. Op. cit., p.26.

126. KERN, H. \& SCHUMAN, M Das Ende der Arbetsleiung? Rationalisiering in der Industriellen Produktion. Munique, Verlag C. H. Beck, 1984.

127. KERN, H. \& SCHUMAN, M. Idem, ibidem; CAMPBELL, I. "New production concepts? The West German debates on restructuring", Labour and Industry. 2(2):247-280, 1989; HOSS, D. "Technology and work in the two Germanies", in GROOTING, (Org.) Technology and Work. East-West comparisons. Londres, Croom Helm, pp.231-72, 1986; LITTEK, W. \& HEISSIG, U."Work Organization Under Technological change: sources of differentiation and the reproduction of social inequality in processes of change", in CLEGG, S.R.(Org.) Organization Theory and Class Analysis: new approaches and new issues. Berlin, De Gruyter, pp.289314,1989

128. MAURICE, M.; SORGE, A \& WARNER, M. "Societal Differences in Organizing Manufacturing Units: a comparion of France, West Germany and Great Britain". Organization Studies 1(1):59-86, 1980. SORGE, A. \& STREECK, W."Industrial Relations and Technical Change: the case for an extended perspective", In HYMAN, R. \& STREEK W.(Org.) New Technology and Industrial Relations. 0xford Blackwell, pp.19-47, 1988; LANE, C. "Industrial Change in Europe: the pursuit of flexible specialization in Britain and West Germany", Work, Employment and Society. 2(2):141-68, 1988. 
129. KERN, H. \& SCHUMANN, M. Op. cit.

138. CAMPBELL, I. Op. Cit.

131. PIORE, M.J. \& SABEL, C.F. Op. cit.

132. CAMPBELL, I. Op. cit

133. KERN, H. \& CHUMANN, M Op. cit.

134. BOREHAM, P.; CLEGG S.R. \& DOW, G. "The Institutional Management of politics: beyond and labour process and corporatist debates", in KNIGHTS, D. \& WILLMOTT, H. (Org.) Managing the Labour Process. Aldershot, Gower, pp.186-210, 1986 automobilística, máquino-ferramenteira e química efetivamente estavam ocorrendo novos fenômenos sociais de reestruturação e incentivo à especialização. No passado, sob os auspícios do que a literatura denominou fordismo, as informações que o trabalhador tinha a dar eram apenas tacitamente reconhecidas $\mathbf{e}$ não raro eram combatidas e marginalizadas. Com os anos, novas formas de reestruturação nos setores principais da economia estão produzindo novas formas de organização do trabalho e "novos conceitos de produção" nos quais as informações dos trabalhadores está implícita e é até mesmo enfatizada, em vez de combatida. Conforme a tradução de Campbell, "as competências relativas à especialização e à perícia dos trabalhadores são forças produtivas que deveriam ser mais amplamente utilizadas"129. Isto está ocorrendo com a, digamos, "re-especialização" do trabalho de produção em tarefas a requererem trabalhadores multi-qualificados. $\mathrm{Na}$ indústria automobilística, isto se deve à reestruturação com vista a processos mais integrados; na indústria máquino-ferramenteira, isto se deve às oportunidades de valorìzação das especializações ocasionadas pelas máquinas controladas por computadores; na indústria química, os trabalhadores estão se profissionalizando cada vez mais, o que está gerando "um conhecimento e uma competência mais abrangentes nas áreas química e mecânica, de modo que reparos e consertos podem ser feitos sem se recorrer a uma equipe de especialistas" 130 . Verifica-se haver em comum um processo de especialização a criar um novo tipo de trabalhador através de um maior treinamento, um trabalhador qualitativamente diferente do ideal de artesão, uma vez que está muito mais intimamente integrado na estrutura geral do controle administrativo.

Para explicar essa mudança recorremse a vários fatores, inclusive a ênfase, familiar desde o trabalho de Piore \& Sabel $^{131}$, no mercado de produção. Idílios improváveis com a mão-de-obra artesanal são evitados, enquanto que novos fatores são enfatizados. Estes incluem mudanças no mercado trabalhista provenientes do desemprego estrutural, que fortalece o controle administrativo. Em vez de utilizá-las com fins contestatórios, como fez-se no passado, pelo menos nos setores centrais das principais organizações de alta margem de lucro da economia, a emergência de novas tecnologias com o aumento da razão entre capital constante e variável do poder trabalhista significa que uma atitude mais favorável para com este último é possível. Ela é até mesmo necessária para evitar-se interrupções custosas na produção, e porque os novos processos exigem uma força de trabalho muito mais qualificada - mesmo nos interstícios das novas tecnologias. ${ }^{132}$ Esta reestruturação, no entanto, é uma faca de dois gumes: ao mesmo tempo que produz um grupo de trabalhadores mais privilegiados, outros serão consignados para o lado inferior da nova segmentação do mercado de trabalho em virtude do status quo da indústria ou da organização, e possivelmente devido a características discriminatórias e a deficiências na formação de capital humano por parte das empresas. Estas duas faces são o verso e o reverso da reestruturação capitalista.

$\mathrm{Um}$ aspecto interessante do argumento de Kern \& Schumann ${ }^{133}$ é a necessidade de reconhecer que disputas políticas são travadas dentro da administração e entre seus integrantes quanto à conveniência de introduzir novos conceitos de produção. Os autores advogam que o movimento trabalhista, em vez de opor-se a mudanças, deveria buscar alianças estratégicas junto às forças progressistas na administração e apressar o desenvolvimento de forças produtivas e relações sociais com vista à produção. Com efeito, o que está sendo reconhecido é que a tradicional concepção marxista da política de produção como um jogo de soma zero não é mais muito útil. Quando relações biunívocas entre trabalhadores e a administração dependem muito mais da formação de especializações e de capital que da exploração extensiva do poder bruto dos trabalhadores, a concepção de jogo soma zero aplicada ao processo de trabalho como um locus das lutas de classes não desempenha outro papel que um discurso retórico. Não apenas as políticas de produção podem dar lugar à produção de políticas na arena política, por intermédio de práticas de sindicalismo político e de negociações corporatistas ${ }^{134}$, como 
também as negociações junto às empresas podem produzir empates entre o trabalhadores e o capital nos termos das condições em que operam. Tais mudanças não parecem apressar o impulso revolucionário ou estimular muitos trabalhadores indolentes para as exigências da luta de classes. A história passada das relações trabalhistas e das políticas democráticas nas sociedades avançadas deveriam servir para que sejamos bastante céticos, não só quanto ao potencial das políticas passadas e dos modos de luta como meios de conseguir esses resultados, mas também quanto à existência de um fundamento nesses meios e fins supostamente desejáveis. Tampouco se deve recorrer a argumentos de hegemonia para salvar os meios e os fins da indiferença daqueles a quem eles supostamente servem, como foi salientado em outra ocasião. ${ }^{135}$

As sugestões de Kern \& Schumann ${ }^{136}$ quanto ao modo como a política sindical deveria se desenvolver face às oportunidades advindas com a "flexibilização" exigem as seguintes estratégias:

1. "Uso harmonioso da massa total de funções qualificadas associadas às novas tecnologias para estabelecer definições de trabalho complexos de modo a abranger o maior número possivel de trabalhadores;

2.Influência nos requisitos para o ingresso em novas áreas para diminuir a competição e a divisão na força de trabalho;

3.Criação de empregos substitutivos adequados e satisfatorios para os trabalhadores deslocados quando novas tecnologias são adotadas para abolir empregos restritivos;

4.Desenvolvimento de processos de treinamento baseados num conceito abrangente de qualificação mas distintos das reivindicações específicas aos processos individuais no local de trabalho; isto implica numa orientação com vistas ao trabalho profissional autônomo e na aceitação da aplicabilidade do saber e das especializações adquiridos fora do local de trabalho;
5.Transparência e regulamentação das novas exigências de desempenho para impedir uma determinação unilateral da parte da administração e evitar qualquer obstrução da possibilidade de definições mais amplas de empregos em vista das pressões de intensificação" ${ }^{137}$

Campbell ${ }^{138}$ critica alguns aspectos implícitos na abordagem de Kern \& Schumann. ${ }^{139}$ Eles lidam com tendências, mas se elas irão ou não marcar época é uma questão empírica, e não uma conjetura teórica. Não se deve enfatizar demais o controle administrativo do processo trabalhista: a mão-de-obra pode ser um custo marginal em muitas indústrias altamente tecnológicas e raramente o foco principal de atenção estratégica. O que está em xeque não é apenas o controle administrativo e a autonomia da mão-deobra, mas questões complexas mais gerais de produção.

Em termos analíticos, foram Badham \& Matthews ${ }^{140}$ os autores que estiveram bem perto de captar os processos distintivos envolvidos no âmago tecnológico dos novos sistemas de produção, concebidos como o foco central de organizações supostamente pós-modernas. Partindo de autores como Child, Perrow e Sorge \& Streek, ${ }^{141}$ eles construíram um modelo tridimensional que estaria no centro de qualquer barganha entre representantes dos trabalhadores e da administração em disputas quanto à forma da organização.

O modelo tridimensional de Badham \& Matthews foi construído em torno do grau de inovação do produto, de variabilidade do processo e de dificuldade. A inovação do produto é identificada pela freqüência com que muda e o seu grau de variação. A variabilidade do processo é identificada pela freqüência e pelo grau de mudanças nos métodos de produção. O grau de dificuldade, em termos do tempo necessário para se aprender o novo sistema exigido por essas mudan-
135. CLEGG, S.R. Power, Rule and Domination: a critical and empirical understanding of power in sociological theory and organizational life. $0 \mathrm{p}$. cit.

136. KERN, H. \& CHUMANN, M. Op. cit.

137. CAMPBELL, I. Op. Cit. p.261.

138.CAMPBELL, I. Op. Cit. p.273.

139. KERN, H. \& CHUMANN, M. Op. cit.

140. BADHAM, R. \& MATTHEWS, J. Op. cit.

141. CHILD, J. "Information technology, organization and the response to strategy challenge". Op. cit.; PERROW, C. Organizational Analysis: a sociological review. Londres, Tavistock Publications, 1971. SORGE, A. \& STREECK, W. Op. cit. 
142. FOX, A. Op. cit.

143. CLEGG, S.R. \& DUNKERLY, D. Op. cit. Cap. 9.

144. Ver CLEGG, S.R.; BOREHAM, P. \& DOW, G. Op. cit. Cap. 9.

145. KAPLINSKY, R. Automation: The technology and society. Londres, Longman, 1984.

146. BADHAM, R. \& MATTHEWS, J. Op. cit. p.209.

147. PEREZ, C. "Microelectronics, Long Waves and World Structural Changes: new perspectives for developing countries", World Development. 13(3):44163, 1985. ças (Badham \& Matthews). Essas dimensões podem mudar independentemente, embora sua autonomia seja apenas relativa, isto é, não são totalmente independentes, mas cada uma impõe limites variáveis nas outras.

O que condiciona os limites da autonomia relativa dessas dimensões são as relações poder/confiança, que Fox ${ }^{142}$ concebeu como mediadora entre o controle administrativo e o consentimento dos empregados. Como se sabe, essas relações podem variar muito, desde configurações de alta confiança/alto arbítrio $\bullet \bullet \bullet \bullet \bullet \bullet \bullet \bullet \bullet \bullet \bullet \bullet \bullet \bullet \bullet \bullet \bullet \bullet \bullet \bullet$

A história das relações trabalhistas $e$ das políticas democráticas nas sociedades avançadas deveriam servir para que sejamos bastante céticos,(...) mas também quanto à existência de um fundamento nesses meios e fins supostamente desejáveis.

até configurações de baixa confiança/baixo arbítrio, capazes de engendrar um "círculo vicioso de controle". ${ }^{143}$

Muitas variáveis ambientais afetam a calibragem do controle organizacional mais ou menos fundamentado nos pólos alta confiança/alta autonomia/alta responsabilidade ou baixa confiança/baixa autonomia/baixa responsabilidade. Condicionar o uso desses pólos não só será características substantivas específicas dos grupos ocupacionais em questão, como o caso da contigência estratégica, como será também aspectos mais gerais da configuração política, particularmente quando são considerados conceitos do "direito do cidadão". Estes podem ser mais ou menos limitados com respeito às esferas de democracia industrial ou econômica. $\mathrm{O}$ caso mais óbvio é o da Suécia $^{144}$, onde esses direitos são amplos. Em conjunto com questões relativas à estrutura do mercado trabalhista (solidário ou segmentado), a questão da cidadania está estreitamente vinculada às capacidades organizacionais do movimento trabalhista, assim como questões relativas à negligência organizacional estão disponíveis nos recursos que eles, e outros participantes, estão preparados para transferir para a arena organizacional em questão.

Qualquer organização, setor ou indústria pode ser caracterizada em termos deste modelo, seja o processo de produção (onde ele está realmente ope- rando num dado ponto no tempo), seja a estratégia de produção (onde o ponto de operação almejado estaria num ponto futuro no tempo). O conceito de processo de produção refere-se ao desempenho de um certo número de funções associadas com o projeto, a coordenação e a produção. ${ }^{145}$ Estas funções incluem " $a$ combinação e a organização de matériasprimas, equipamentos e pessoal para projetar, planejar e fabricar um produto". 146

A noção de estratégia de produção representa o resultado dos processos que determinam o cálculo limitadamente racional dos objetivos mais ou menos coerentes e preferidos dos mandatários da organização. Naturalmente, um elemento decisivo no estabelecimento de limites e possibilidades dos processos incrementais envolvidos na formulação de estratégias será o poder de outros atores estratégicos dentro e em torno da organização, bem como da aceitação institucionalizada do que é possivel, desejável e racional em termos de capital cultural implicado no processo. As fontes são muitas; envolvem não apenas especificações de organizações estatais (como as derivadas de instrumentalidades responsáveis pela saúde e pela segurança, igualdade de oportunidades, reestruturação etc.), mas também concepções profissionais e ocupacionais do desiderato racional, assim como outros protagonistas, como os vários meios de transmissão de informação em consultorias, universidades, periódicos, revistas e outros meios de comunicação. Alguns pesquisadores como Perez ${ }^{147}$, incluiriam neste rol de fatores institucionais forças arquitetônicas estruturais consideradas conglomerados de "paradigmas tecnoeconômicos" distintos em torno de pontos-chave em longas ondas de inovação tecnológica. A pós-modernidade seria então caracterizada pela estruturação e pela afinação fornecidas pela relativa disponibilidade e pelo baixo preço da nova informática microeletrônica, do mesmo modo como a disponibilidade de petró- 
leo barato foi o ponto arquitetônico da longa onda anterior. Não é preciso aceitar esta perspectiva macroscópica para atentar que é através dos processos de poder/instituições que as racionalidades possíveis que unem processos e estratégias são negociadas e disputadas. A visão da "longa onda" simplesmente fornece numa explicação temporária para a disponibilidade dos modos de racionalidade em sua especificidade histórica.

Dadas essas noções do processo e da estratégia da produção, é possível uma conceituação abran-

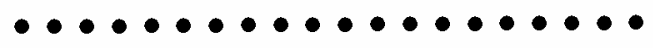

Ainda é cedo para saber se estamos entrando num periodo de especialização flexível, de modo que possíveis implicações no emprego, na organização e na especialização do trabalho são ainda incertas. gente nos termos dos modos de racionalidade embutidos. Uma questão crucial aqui é a negociação, não só dos aspectos materiais da produção como a inovação de produtos e a variabilidade do processo, como também da questão muito mais complexa e indeterminada da responsabilidade da mão-de-obra, ou o que Fox ${ }^{148}$ denominou relações poder/confiança.

Teóricos que consideram os sistemas de produção flexível simplesmente mais um instrumento de controle, "des-especialização" e "degradação" dos trabalhadores, como é o caso de Pollert ${ }^{149}$, podem muito bem estar caracterizando com precisão seu uso quando implementado no modo neofordista de racionalidade, conforme sugerem Badham \& Matthews: "Consciente do potencial flexível de novas tecnologias e da necessidade de formas limitadas de responsabilidade do trabalhador, as estratégias administrativas nesta área irão se concentrar no maior desenvolvimento tecnológico numa direção que supere as necessidades a curto prazo para o incremento de especializações e responsabilidades do trabalhador. ${ }^{150}$

É possível antecipar que o interesse de um movimento trabalhista seria deslocar o maior número possível de empresas nacionais para o eixo pós-fordista. Pesquisas sugerem que a sorte está contra essa mudança - mas saber o que a sorte reserva é o primeiro passo na busca de maneiras de jogar malgrado as desvantagens. Ainda é cedo para saber se estamos entrando num período de especialização flexível, de modo que possíveis implicações no emprego, na organização e na especialização do trabalho são ainda incertas. Estudos mostraram quão limitadas são as intenções da administração quanto à "des-especialização". Shaiken et alii, Buchanan e Wilson ${ }^{151}$ delinearam diferentes modos como novas demandas foram impostas à força de trabalho - orçamentos de programas precisaram ser revistos e o processo de produção precisou ser monitorado. $\mathrm{O}$ saber dos trabalhadores revelou-se essencial nesse processo.

Este saber não era de certo modo "externo" aos circuitos de poder que estruturavam o trabalho mas era parte integrante das instituições. Perrow ${ }^{152}$ já havia oferecido alguns exemplos divertidos e assustadores das desastrosas conseqüências decorrentes quando ignora-se o papel da força de trabalho nos sistemas de controle automatizado de sistemas de navegação e aviação que geram poder. As intenções da administração muitas vezes são visionárias ${ }^{153}$, pouco práticas, visionárias, resistidas e nem sempre se realizam. ${ }^{154}$

Wilson \& Buchanan ${ }^{155}$ argumentam que, quando os produtos e os processos permitem, haverá uma tendência geral para a "des-especialização". Esta posição é muito determinista: o que importa é a configuração de poder a estruturar ambientes particulares. A pesquisa destes autores sugere que, quando especializações são perdidas, a experiência será semelhante nas forças de trabalho em diferentes fábricas.

A introdução de novas tecnologias fornece aos administradores uma oportunidade para alterarem o trabalho e a "des-especialização" onde reputarem possível ou desejável. O trabalhador pode ser treinado somente até ser ca-
148. FOX, A. Op. cit.

149. POLLERT, A. Op. cit.

150. BADHAM, R. \& MATTHEWS, J. Op. cit. p.208.

151. BUCHANAN, D.A. "Using the New Technology: management objectives and organization choices". European Management Journal. 1:70-79, 1982; BURNES, B. "Factors affecting the introduction and use of computer numeric controlled machine tools". Trabalho apresentado no Internation Conference on Human Factors in Manufacturing, Londres, 3 a 5 de abril 1984; SHAIKEN, $H$. et alii. Op. cit.; WILKINSON, R. The shopfloor politics of new technology. Londres, Heinmann, 1983.

152. PERROW, C. Op. cit.

153. TOWILL, D.R. "A production engineering approach to robot selection", Omega. 12(3):261-272, 1984.

154. BUCHANAN, D.A. Idem, ibidem; BURNES, B. Idem, ibidem; NOBLE, D.F. "Social Choice in Machine Design: the case of automatically controlled machine tools", in ZIMBALIST, A.(Org.) Case studies in the labor process. Nova lorque, Monthly Review Press, 1979.

155. WILSON, F.M. \& BUCHANAN, D.A. "The Effect of New Technology in the Engineering Industry: cases of control and constraint", Work, Employment and Society. 2(3):366-380, 1988. 
156. HYMAN, R. Op. cit. pp.4860 .

\section{WATANABE, T. Op. cit}

158. JONES, W. "Quality's vicious circles", Management Today. pp. 97-103, março 1983.

159. WILSON, F.M. Productive efficiency and the employment relationship - the case of quality circles", Employee Relations. 11(1):27-32, 1989

160. SCHONBERGER, R. Japanese Manufacturing Techniques: nime hidden lesson in simplicity. Nova lorque, Free Press, 1983.

161. SHAIKEN, H.; HERZENBERG, H. \& KUHNS, S. Op. cit.

162. BRAMBLE, T. Op. cit

163. MARCHINGTON, M. Managing industrial relations. Maidenhead, McGraw Hill, 1982.

164. RAMSAY, H."Cycles of control, worker participation in sociological and historical perspectives". Sociology, 2, 1977.

165. CRESSEY, P. \& McINNES $\mathrm{J}$. "The recession and industrial relations". Trabalho apresentado na Conferência do ESRC, University of Warwick, e citado em MARCHINGTON, M. \& ARMSTRONG, $R$. "The nature of the new joint consultation", Industrial Relations Journal. 17 verão de 1986/1985. paz de realizar as operações revistas. Como argumentam os neo-fordistas, as novas especializações podem não ser transferíveis de uma empresa a outra. Hyman observou que a "administração delegada não se equipara à auto-administração, assim como um acervo de competências desgastadas não se equipara ao aumento de especializações. "156

A administração delegada depende do empenho da força de trabalho. As velhas relações de antagonismo, alimentadas pelas lendas de luta de classes, provavelmente não fornecerão uma base adequada para os tempos (pós?)-modernos. $\mathrm{O}$ empenho da força de trabalho tornou-se uma das principais preocupações por força da necessidade de envolver os empregados não apenas no desenvolvimento das especializações necessárias para operar eficientemente a tecnologia, como também para que possam participar de círculos de qualidade. Isto acrescenta ao rol das responsabilidades do trabalhador o controle da qualidade como parte do plano de atingir a Administração da Qualidade Total, o que implica em mais exigências a serem cumpridas por ele. Em vez de considerar essas iniciativas qualitativas um exemplo da possibilidade de compartilhar poder, como seria evidente para a perspectiva que considera o poder um jogo de soma zero, seria mais adequado encará-las como outro circuito potencial, através do qual mais poder poderá fluir, novas práticas disciplinares poderão ser desenvolvidas e, a partir dessas últimas, um incremento de poder poderá ocorrer. Círculos de qualidade podem aumentar ou diminuir o poder: uma utilidade eventual meramente reside no fato de permitirem que a administração faça uso do saber minuncioso detido pela força de trabalho para diagnosticar e resolver problemas de produção ou de qualidade. Watanabe ${ }^{157}$, contudo, argumentou que círculos de qualidade podem ser introduzidos para contrabalançar a simplificação dos empregos e a alienação dos trabalhadores. Em iniciativas desse tipo, os trabalhadores precisam empenhar-se na sua relação com o emprego. É improvável que os trabalhadores invistam tempo e esforço se a única recompensa for psicológica. ${ }^{158}$ Onde residirá a iniciativa de participar se a recom- pensa for negativa, se, por exemplo, os tempos e os cálculos das funções forem revistos, o que poderá ocasionar corte nos salários? ${ }^{159}$

É importante diferenciar as mudanças nas técnicas de trabalho e não tratá-las como um todo. Por exemplo, pode-se argumentar, valendo-se dos métodos de produção "de última hora" (da expressão em inglês just-in-time, abreviada em JIT), que a filosofia representa a intensificação dos métodos tailoristas de organização do trabalho. ${ }^{160} \mathrm{~A}$ administração é mais capaz de identificar áreas inativas e, conforme o argumento de Shaiken ${ }^{161}$, métodos de produção de última hora oferecem a oportunidade de introduzir linhas de montagem acompanhando áreas de produção em lotes antes até certo grau sujeitas ao controle de um operador. Evidências coletadas por Bramble ${ }^{162}$ na Australian Metal Industry revelaram como o sistema baseado em métodos de produção de última hora permitiu que a administração aumentasse a vigilância e a intensidade do controle. $\mathrm{O}$ resultado para os trabalhadores da produção foi a constante intensificação do trabalho, a ampliação das operações de rotina executadas por cada pessoa e a redução da manipulação.

$O$ repentino aumento do interesse em esquemas participativos nos anos 80 poderia ser interpretado como uma resposta da administração para o declínio econômico e industrial, o que foi cruamente parafraseado na frase "vamos nos juntar ou vamos desmontar"163. Ramsay ${ }^{164}$ argumentou que quando a administração enfrenta uma crise, geralmente em consequência de ameaças econômicas externas, desenvolvem-se esquemas de participação para garantir a anuência dos trabalhadores. Um abrandamento da ameaça geralmente coincide com uma diminuição do interesse na participação. Qualquer "democracia salva-vidas" é extremamente frágil e naufragará de encontro aos rochedos das prerrogativas administrativas. ${ }^{165}$

Seria possível afirmar o mesmo a respeito de algumas iniciativas de qualidade? O aumento de autonomia que elas acarretam podem estimular a força de trabalho a acreditar estar participando de um processo que reflete suas necessidades, suas especializações e suas escolhas, 
muito embora seja óbvio não ser esta a intenção da administração. Mas qual seria a importância desses objetivos? Se o objetivo dos administradores serniors for atingir lucros constantes e elevados, e mobilizar a anuência para aumentar a produtividade, em vez de atender às necessidades dos trabalhadores, importa se durante o processo sejam criados novos canais de poder que podem ser utilizados produtivamente pela força de trabalho?

\section{CONCLUSÕES}

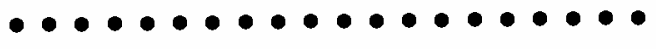

\section{$O$ repentino aumento do interesse em} esquemas participativos nos anos 80 poderia ser interpretado como uma resposta da administração para o declínio econômico e industrial.
O locus do controle nem sempre pode ser transferi-

mente a obediência. Tudo depende da disposição dos subordinados de submeterem-se ao controle administrativo, e do sucesso das administrações em assegurar o tipo de circulação de poder que lhes permitam realizá-lo. $O$ argumento deste artigo é que pode ser um erro conceitual e uma desvantagem considerar que isso exige uma relação de poder de soma zero. Resultados de soma positiva que não sejam resultantes simplesmente de manipulação mas que ofereçam contingências potencialmente frutíferas e políticas verdadeiras são possíveis. Basta do dos trabalhadores para os administradores, nem dos administradores para os trabalhadores durante uma mudança técnica. Em última instância, o controle está nas mãos da administração, e é um objetivo administrativo fundamental, não porque os administradores sejam necessariamente tiranos visando à dominação dos trabalhadores. (Alguns até podem ser! - não raro acarretando resultados desastrosos para a organização.) Os administradores são considerados responsáveis pelo controle nas várias formas, nos vários níveis e nas várias disciplinas que ele assume. Portanto, eles têm influência nos circuitos de poder, quer queiram, quer não. É isso que os torna condutores através dos quais flui a responsabilidade por várias ações organizacionais: por exemplo, aumento na produtividade e redução da incerteza no processo produtivo. ${ }^{166}$ Especialistas em delinear tarefas demonstraram que o aumento da especialização e do arbítrio da força de trabalho em geral não é incompatível com o controle organizacional efetivo da produção. Se estas formas de delegação organizacional de poder podem gerar maior produtividade, porque os administradores não adotam essa linha de pensamento com maior freqüência?

Não há um sistema de controle administrativo que possa eliminar totalmente $o$ arbítrio do empregado ${ }^{167}$, nem relações de autoridade que possam comandar inteira- procurá-las. Isso significa abandonar os preconceitos analíticos profundamente enraizados contra o poder. Significa também que precisamos repensar as organizações.

As organizações não irão necessariamente se transformar em utopias neo-românticas, como propõem algumas perspectivas fechadas à conta de sua interpretação do que acarretaria transformar-se em japonês. Mas não é assim naquele país, e interpretações erradas não irão propiciar que o mito se torne realidade em outros lugares. Igualmente, as organizações não serão necessariamente recipientes neutros por onde poderá fluir como maná a razão pura da eficiência e eficácia, formalizada em termos puramente técnicos. Elas sempre compõem-se de relações sociais. Outrossim, as organizações não precisam ser necessariamente concebidas como bigornas onde a classe trabalhadora possa ser indefinidamente forjada com marteladas oriundas das prerrogativas e do poder da administração. O poder não é inteiramente equivalente às oportunidades dadas à força bruta. Ao contrário, as contingências do poder e das organizações são complexas, interdependentes e, até certo ponto, potencialmente capazes de mudar. Naturalmente, isto é mais provável em alguns lugares com algumas estruturas institucionais do que em outros, mas isto já é uma outra "estória". ${ }^{168} \square$
166. THOMPSON, J.D. Organizations in Action. Nova lorque, McGraw-Hill, 1967.

167. CLEGG, S.R. Organization and control. Op. cit.

168. CLEGG, S.R. Modern organizations. Op. cit. 